\title{
Baccharis subgen. Molina (Asteraceae) no estado do Rio de Janeiro, Brasil ${ }^{1}$
}

Baccharis subgen. Molina (Asteraceae) in Rio de Janeiro state, Southeast Brazil

\author{
Gustavo Heiden $^{2,5}$, José Fernando Andrade Baumgratz ${ }^{3}$ \& Roberto Lourenço Esteves ${ }^{4}$
}

\begin{abstract}
Resumo
Baccharis compreende ca. 340 espécies distribuídas nas Américas. O indumento em tufos diminutos, formado por tricomas com uma única célula basal, e as flores funcionalmente unissexuais são caracteres diagnósticos do gênero. No estado do Rio de Janeiro ocorrem 55 espécies de Baccharis. O trabalho apresenta os resultados de estudos taxonômicos de Baccharis subgen. Molina (Pers.) Heering para a flora fluminense. No estado, o subgênero está representado por 18 espécies pertencentes a quatro seções - Caulopterae (8 spp.), Molinae (4 spp.), Baccharidastrum (3 spp.) e Trinervatae (3 spp.). É apresentada uma chave para a identificação das seções e espécies e descrições morfológicas, ilustrações, dados de distribuição geográfica e ecologia. Três espécies são novos registros e cinco são excluídas da lista de espécies do Rio de Janeiro.
\end{abstract}

Palavras-chave: Astereae, Compositae, Campos de Altitude, Mata Atlântica, Restinga.

\begin{abstract}
Baccharis comprises c. 340 species occurring in the Americas. The tufted indumentum, with trichomes having a single adjoining basal cell, and florets functionally unisexual are diagnostic characters of the genus. The Rio de Janeiro state flora contains 55 species of this genus. This work presents the results of taxonomic studies of Baccharis subgen. Molina (Pers.) Heering in Rio de Janeiro state. The subgenus is represented by 18 species belonging to four sections - Caulopterae ( 8 spp.), Molinae (4 spp.), Baccharidastrum (3 spp.), and Trinervatae (3 spp.). A key for the identification of sections and species, plus morphological descriptions, illustrations, and comments on geographic distribution and ecology are provided. Three species are new records and five are excluded from the state checklist of species.
\end{abstract}

Key words: Astereae, Compositae, High Altitude Grasslands, Atlantic Rain Forest, Coastal Vegetation.

\section{Introdução}

Baccharidinae (Asteraceae) é constituída por Archibaccharis Heering, com 32 espécies, e Baccharis L. com ca. 340 espécies (Müller 2006, 2010), distribuídas nas Américas, do sul do Canadá ao sul da América do Sul (Fielding 2001; Giuliano 2001). O indumento em tufos diminutos, formado por tricomas com uma única célula basal, e as flores funcionalmente unissexuais são caracteres diagnósticos do gênero (Müller 2006).

Desde Candolle (1836), Baccharis nunca foi revisado taxonomicamente por completo. $\mathrm{O}$ último tratamento taxonômico para o Brasil foi publicado por Barroso (1976), que aceitou 125 nomes. Atualmente, são registradas 167 espécies no país (Heiden \& Schneider 2012). Pertencentes a quatro subgêneros e 21 seções. $O$ gênero ocorre em todos os biomas brasileiros, sendo que a maioria das espécies é encontrada nas Regiões Sul, Sudeste e Centro-Oeste. No estado do Rio de Janeiro, a maior diversidade de espécies de Baccharis é encontrada em refúgios ecológicos montanos (afloramentos rochosos e inselbergues) e altimontanos (campos de altitude), embora também

\footnotetext{
${ }^{1}$ Parte da dissertação de Mestrado do primeiro autor desenvolvida na Escola Nacional de Botânica Tropical, Instituto de Pesquisas Jardim Botânico do Rio de Janeiro.

${ }^{2}$ Universidade de São Paulo, Depto. Botânica, Instituto de Biociências, R. do Matão, Trav. 14, 321, São Paulo, SP, 05508-900, Brasil.

${ }^{3}$ Instituto de Pesquisas Jardim Botânico do Rio de Janeiro, R. Pacheco Leão 915, Rio de Janeiro, RJ, 22460-030, Brasil.

${ }^{4}$ Universidade do Estado do Rio de Janeiro, Centro Biomédico, Depto. Biologia Animal e Vegetal, R. São Francisco Xavier 524, Rio de Janeiro, RJ, 20550-900, Brasil.

${ }^{5}$ Autor para correspondência: gustavo.heiden@gmail.com
} 
ocorram espécies características de Florestas Altimontanas, Montanas e Submontanas ou de Restingas. Os quatro subgêneros de Baccharis, 15 seções e 55 espécies estão representados na flora fluminense (Heiden 2009).

Este trabalho apresenta os resultados de estudos taxonômicos de Baccharis subgen. Molina (Pers.) Heering no estado do Rio de Janeiro. As espécies estudadas são posicionadas em seções e uma chave para a identificação das seções e espécies no Rio de Janeiro é fornecida. Além disso, são apresentadas descrições morfológicas, ilustrações, dados de distribuição geográfica e ecologia, comentários nomenclaturais e taxonômicos.

\section{Material e Métodos}

A área de estudo compreende o estado do Rio de Janeiro, Sudeste do Brasil, entre os paralelos $20^{\circ} 45^{\prime} 56^{\prime \prime} \mathrm{S}$ e $23^{\circ} 22^{\prime} 08^{\prime \prime} \mathrm{S}$ e os meridianos $40^{\circ} 57^{\prime} 23^{\prime}$ 'W e 445 $53^{\prime} 19^{\prime}$ 'W, estando totalmente inserido no Bioma Mata Atlântica.

Os dados obtidos resultam de revisão bibliográfica e, principalmente, de análise de coleções históricas e recentes, incluindo tipos e fotos de tipos, disponíveis nos herbários B, C, CEPEC, CESJ, ESA, F, FCAB, G, GUA, HAS, HB, HBG, HBR, HPNI, HRJ, HUEFS, IAC, ICN, IPA, JPB, K, M, MBM, MBML, MG, MO, NY, P, PACA, PEL, R, RB, RBR, RFFP, RUSU, S, SP, SPF, UEC, UFP, UFRN, UPCB, US e W, e de expedições científicas realizadas ao longo do território estadual entre os anos de 2007 e 2008, para coleta de material botânico, observação das espécies em campo e obtenção de dados ecológicos. O material coletado foi herborizado segundo técnicas usuais e incorporado no acervo do herbário RB, com duplicatas enviadas aos herbários K, JE, PEL, R, RBR, SP e SPF.

São fornecidas chaves analíticas para a identificação das seções e espécies com base nos táxons ocorrentes no estado do Rio de Janeiro, sendo que as descrições são diagnósticas e limitadas às espécies ocorrentes no território fluminense. Uma lista abrangente de sinônimos, assim como uma lista completa do material examinado e tipos podem ser consultados em Heiden (2009). São fornecidas ilustrações ou indicações bibliográficas de ilustrações imediatamente após a citação do protólogo de cada espécie. Espécies anteriormente citadas para o estado do Rio de Janeiro, mas cuja ocorrência não pôde ser assegurada devido à inexistência de material testemunho, são apresentadas em uma listagem de espécies excluídas. Os nomespopulares fornecidos foram obtidos nas etiquetas de exsicatas, em levantamentos etnobotânicos ou diretamente com informantes da população local, sendo que a fonte da informação é citada após os nomes fornecidos na forma autor/data ou coletor/ número do espécime. Os dados fenológicos se referem aos espécimes coletados na área de estudo. A delimitação dos biomas brasileiros segue IBGE (2004).

A terminologia utilizada para a descrição das características morfológicas baseia-se em Radford et al. (1974) e Müller (2006). Na maior parte das espécies de Baccharis, ramos, folhas e brácteas involucrais são recobertos por um microindumento, geralmente completamente encoberto e obscurecido por uma camada de resina, conferindo às estruturas das plantas um aspecto falsamente glabro. Dessa forma, muitas espécies do gênero são comumente descritas como glabras ou pontoado-glandulosas, embora na realidade apresentem esse microindumento formado por diminutos tufos de tricomas com uma única célula basal, e não por glândulas simples ou tricomas glandulares (Müller 2006). Esse microindumento, geralmente invisível à olho nu, pode estar ou não associado com outros tipos de tricomas. Dessa forma, para fins práticos de identificação, no presente tratamento plantas que apresentam apenas o microindumento em diminutos tufos de tricomas são referidas como "aparentemente glabras", enquanto que nos casos em que esse microindumento está associado com outros tipos de tricomas, o indumento perceptível a olho nu é descrito.

Mapas foram confeccionados com o auxílio do aplicativo DIVA-GIS 5.4. A obtenção das coordenadas de distribuição geográfica foi padronizada com o georreferenciamento das localidades de coleta indicadas na etiqueta, utilizando as coordenadas fornecidas pelo aplicativo Google Earth ${ }^{\circledR}$, que utiliza o Datum WGS-84. Para a plotagem dos pontos de ocorrência, foi utilizada a projeção de Lambert. Os dados utilizados para a avaliação do estado de conservação das espécies são oriundos dos estudos taxonômicos. Para a avaliação e apresentação do estado de conservação das espécies no estado do Rio de Janeiro foram seguidas as orientações conforme especificado nos formulários da IUCN (2001). 


\section{Resultados e Discussão}

Taxonomia de Baccharis subgen. Molina (Pers.) Heering no estado do Rio de Janeiro

Baccharis subgen. Molina (Pers.) Heering, Schriften Naturwiss. Vereins Schleswig-Holstein 13: 40. 1904. Molina Ruiz \& Pav., Fl. Peruv. Chil. Prodr., p. 111, t. 24. 1794. Baccharis [sem nível taxonômico designado] Molina Pers., nom. illegit. non Schrank (1789) [Gramineae], nec Cav. (1790) [Malpighiaceae], nec Gay (1833) [Euphorbiaceae], Syn. pl. 2: 424. 1807.

Plantas monóicas ou dióicas. Capítulos disciformes heterógamos, flores bissexuais e femininas, ou homógamos, flores masculinas ou femininas. Capítulo masculino campanulado. Flores masculinas com tubo da corola cilíndrico; ápice do estilete lanceolado, papilas de tamanhos uniformes, indiviso a dividido $\geq 1 / 2$, portando papilas de tamanhos uniformes; papilho unisseriado, cerdas levemente ou não espessadas no ápice. Capítulo feminino cilíndrico ou campanulado. Flores femininas com corola filiforme, ramos do estilete exsertos. Cipselas obscurecidas pelas brácteas involucrais, castanhoclaras ou estramíneas; papilho persistente, cerdoso; cerdas não ou levemente espessadas no ápice.

Baccharis subgen. Molina ocorre do sul dos EUA à Patagônia e compreende ca. 80 espécies (Müller 2006). No Brasil ocorrem sete seções e 50 espécies do subgênero, com ocorrência predominante nas Regiões Sul e Sudeste. No estado do Rio de Janeiro estão representadas 18 espécies de quatro seções, que ocorrem desde restingas, ao nível do mar, até os campos de altitude. A seção Caulopterae DC. é a mais diversificada compreendendo oito espécies, seguida pela seção Molinae (Pers.) Cuatrec., com quatro espécies, e as seções Baccharidastrum (Cabrera) Nesom e Trinervatae DC., com três espécies cada. Dentre as espécies estudadas, quatro são novos registros para a flora fluminense e cinco foram excluídas da lista de espécies do estado.

\section{Chave para identificação das seções e espécies de Baccharis subgen. Molina no RJ}

1. Folhas desenvolvidas, margens serreadas

2. Caule sulcado (sect. Baccharidastrum) 3

3. Capítulos homógamos 2. B. glutinosa

3'. Capítulos heterógamos 4

4. Folhas sésseis, base atenuada 1. B. breviseta

4'. Folhas pecioladas, base obtusa 3. B. vulneraria

2'. Caule liso. (sect. Molinae) 5

5. Panículas e/ou racemos, axilares e/ou terminais; capítulo feminino $\geq 70$ flores ...6 6

6. Lâmina foliar membranácea; capitulescências axilares dispersas ao longo dos ramos; brácteas foliáceas (4-12 × 1-3,5 cm), mais longas que as capitulescências

12. B. oxyodonta

6'. Lâmina foliar coriácea; capitulescências concentradas no ápice dos ramos; brácteas reduzidas ou escamiformes $(0,3-1,5 \times 0,1-0,7 \mathrm{~cm})$, mais curtas que as capitulescências

5'. Panículas apenas terminais; capítulo feminino $\leq 55$ flores 13. B. punctulata

7. Lâmina foliar membranácea, face adaxial fosca, pilosa 14. B. serrulata

7'. Lâmina foliar coriácea, face adaxial brilhosa, pubérula ou aparentemente glabra 7 15. B. stylosa

1'. Folhas desenvolvidas, margens inteiras ou crenuladas, ou folhas escamiformes

8. Capítulos femininos providos de páleas. (sect. Trinervatae) 9

9. Folhas brilhosas; panículas ou racemos piramidais 18. B. trinervis

9'. Folhas foscas; panículas e/ou racemos glomeriformes ou corimbiformes. 10

10. Folhas com 3 nervuras acródromas basais; as mais jovens vilosas, tricomas filiformes; corola das flores masculinas 3,5-4 mm compr.; estilete das flores femininas 3,1-4,2 mm compr.

10'. Folhas com 3 nervuras acródromas suprabasais ou 5 basais, as mais jovens tomentosas, tricomas arbusculares (fusão de tricomas flagelados e filiformes); corola das flores masculinas 2,2-3,4 mm compr.; estilete das flores femininas 1,4-2,6 mm compr. 
8'. Capítulos femininos desprovidos de páleas (sect. Caulopterae) 11

11. Caule áptero

12. Lâmina coriácea, 3 nervuras acródromas basais; panículas $1,5-6 \mathrm{~cm}$ compr.

10. B. organensis

12'. Lâmina cartácea, peninérvea ou 3 nervuras acródromas suprabasais; panículas 4-16 cm compr......

11. B. regnellii

11'. Caule alado. 13

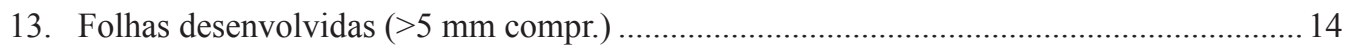

14. Subarbustos $(0,5-1 \mathrm{~m}$ alt.); ramos espiciformes $5-20 \mathrm{~cm}$ compr.

8. B. junciformis

14'. Arbustos (0,5-3 m alt.); ramos espiciformes 0,5-5 cm compr. 15

15. Alas 0,1-0,3 mm larg.; lâmina foliar coriácea, base atenuada........ 5. B. burchellii

$15^{\prime}$. Alas $0,5-1,3 \mathrm{~mm}$ larg.; lâmina foliar papirácea, base cuneada a arredondada ........

7. B. glaziovii

13'. Folhas escamiformes $(\leq 5 \mathrm{~mm}$ compr.) 16

16. Ramos eretos 6. B. crispa

16'. Ramos patentes, decumbentes e/ou prostrados 17

17. Subarbustos $0,2-0,4 \mathrm{~m}$ alt.; capítulo feminino com invólucro urceolado a campanulado; invólucro 8-10-seriado 4. B. altimontana

17'. Subarbustos 1-2,5 m alt.; capítulo feminino com invólucro cilíndrico, invólucro 4-7-seriado. 9. B. myriocephala

I. Baccharis subgen. Molina sect. Baccharidastrum (Cabrera) G. L. Nesom, Phytologia 65: 170. 1988. Baccharidastrum Cabrera, Notas Mus. La Plata, Bot. 2: 175. 1937.

A seção Baccharidastrum compreende três espécies com ocorrência no sudoeste dos EUA, nos Andes e no sudeste da América do Sul. A seção corresponde ao antigo gênero Baccharidastrum Cabrera, caracterizado por capítulos heterógamos, tratado como uma seção de Baccharis por Nesom (1988), juntamente com B. glutinosa Pers., espécie com capítulos homógamos. Barroso (1976) tratou as espécies com capítulos heterógamos em Baccharidastrum, enquanto B. glutinosa (como B. medullosa DC.) foi subordinada ao Grupo Medullosa.

As espécies ocorrentes no Rio de Janeiro são reconhecíveis pelo caule sulcado; folhas viscosas, com ambas as faces aparentemente glabras, com margens serreadas, 3 nervuras acródromas basais; panículas corimbiformes; capítulos heterógamos e homógamos, com clinanto destituído de páleas; corola das flores femininas truncada e com uma coroa subapical de tricomas bisseriados; e cipselas cilíndricas, glabras ou papilosas, 4-6-costadas, papilho unisseriado, não acrescente e cerdas espessadas na base e fundidas formando um anel.
1. Baccharis breviseta DC., Prodr. 5: 402.1836. Ilustração: Cabrera (1974).

Fig. 1

Subarbustos $0,5-1,5 \mathrm{~m}$ alt., monóicos. Folhas sésseis, 1,5-9 × 0,3-0,8 cm; lâmina estreitamente elíptica a lanceolada, ápice agudo, margens serreadas, base atenuada, nervuras acródromas basais. Panículas 20-50 × 10-25 $\mathrm{cm}$; pedúnculos 1-10 mm compr. Capítulos heterógamos, hermafroditas, 3,5-5,8 $\mathrm{mm}$ alt.; invólucro 3-3,8 × 4,3-9 cm, 2-3-seriado; brácteas involucrais externas ovadas, medianas oblongas, internas linear-elípticas, ápice agudo, denteado, margens estreitamente escariosas. Flores masculinas $3-12$; corola $2-2,6 \mathrm{~mm}$ compr., tubo $1,2-1,5 \mathrm{~mm}$ compr., fauce $0,2-0,4$ mm compr., lacínias $0,6-1 \mathrm{~mm}$ compr.; anteras inclusas ou levemente exsertas; estilete 2,4-3,1 mm compr.; papilho 2,6-3,2 mm compr., ápice levemente espessado. Flores femininas 50-90; corola 1,8-2,3 mm compr.; estilete 1,9-2,5 mm compr. Cipselas $0,6-0,8 \mathrm{~mm}$ compr., comprimidas lateralmente, 3-6-costadas, papilosas nas costelas; papilho 2,7-3,5 $\mathrm{mm}$ compr.

Material examinado: Petrópolis, III.1944, O.C. Góes (RB 49623); III.1944, O.C. Góes 339 (RB). Teresópolis, II.1966, A.P. Duarte 9597 (HB, RB).

Material adicional selecionado: BRASIL. SANTA CATARINA: Lages, 20.III.1971, E. Wolniewicz (RB 273839). 


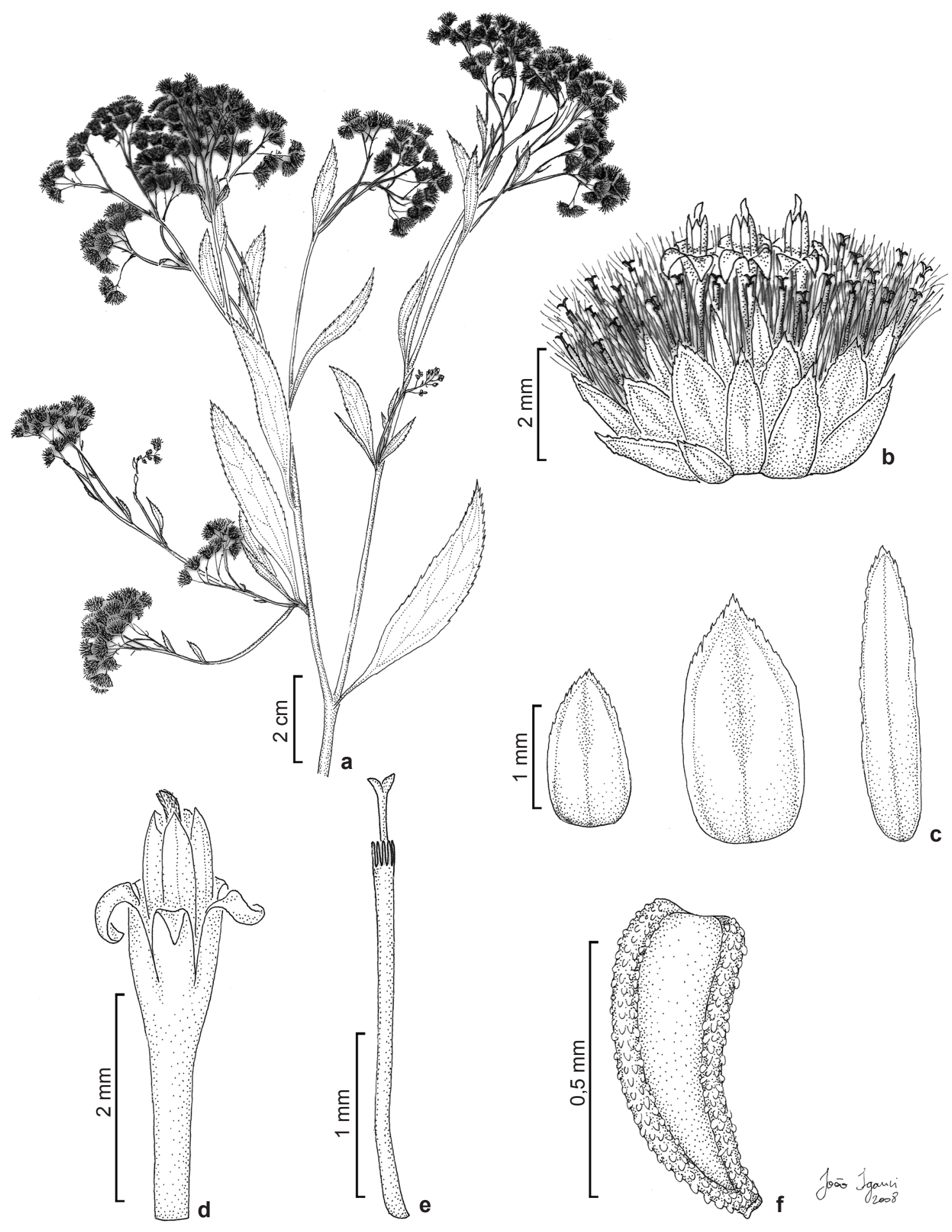

Figura 1 - Baccharis breviseta DC.: a. ramo florífero; b. capítulo; c. brácteas involucrais; d. flor masculina (papilho e ovário vestigial removido); e. corola e estilete da flor feminina; f. cipsela (a-e: Wolniewicz (RB 273839)).

Figure 1 - Baccharis breviseta DC.: a. flowering shoot; b. capitulum; c. phyllaries; d. male floret (pappus and vestigial ovary removed); e. corolla and style of female floret; f. cypsela (a-e: Wolniewicz (RB 273839)). 


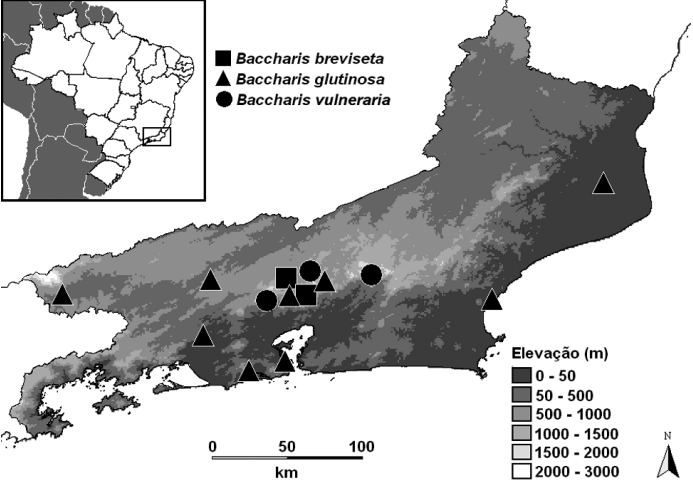

Figura 2 - Distribuição geográfica de Baccharis breviseta DC. (ם), B. glutinosa Pers. (A) e B. vulneraria Baker ( ) no estado do Rio de Janeiro. Figure 2 - Geographic distribution of Baccharis breviseta DC.

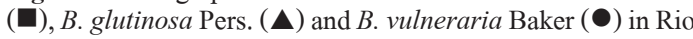
de Janeiro state, Brazil.

Baccharis breviseta apresenta ampla distribuição na América do Sul. Ocorre no Paraguai, Brasil, Uruguai e Argentina. No Brasil é encontrada nas Regiões Nordeste (BA), CentroOeste (DF, GO, MT), Sudeste (MG, RJ, SP) e Sul (PR, SC, RS), nos Biomas Cerrado, Mata Atlântica e Pampa. No estado do Rio de Janeiro (Fig. 2) ocorre entre 600 e $800 \mathrm{~m}$ de altitude, em locais sob influência da Floresta Ombrófila Densa em habitats abertos sob sol pleno, como brejos, várzeas ou áreas antropizadas. Floresce e frutifica de dezembro a março. Erva-santa (Hoehne s.n., SP 305294).

Baccharis breviseta se assemelha com $B$. glutinosa, mas pode ser diferenciada pelas folhas estreitas e sésseis, capítulos heterógamos e corola das flores femininas longa, com 1,8-2,3 mm compr. (vs. folhas largas e pecioladas, capítulos homógamos e corola das flores femininas curta, 1-1,5 mm compr.). Baccharis breviseta é o nome correto para esta espécie, embora o uso do sinônimo Baccharidastrum argutum (Less.) Cabrera seja comum na literatura e em herbários (Heiden 2009).

2. Baccharis glutinosa Pers., Syn. Pl. (Pers.) 2(2): 425. 1807. Molina viscosa Ruiz \& Pav., Syst. Veg. fl. Peruv. Chil. p. 207. 1798. Baccharis viscosa (Ruiz \& Pav.) Kuntze, Rev. gen. pl. 1: 320. 1891 [nom. superfl., non Lam. 1783]. Ilustrações: Cabrera (1974, 1978); Barroso (1976); Malagarriga (1976); Müller (2006).

Fig. 3

Subarbustos $0,2-1,5 \mathrm{~m}$ alt., dióicos. Folhas com pecíolo 0,2-3,5 cm compr.; lâmina 3-11 × 0,3$3,5 \mathrm{~cm}$, elíptica a lanceolada, ápice agudo, margens serreadas, base atenuada; nervuras acródromas basais ou $0,1-1,5 \mathrm{~cm}$ suprabasais. Panículas $15-40$ $\times$ 6-13 cm; pedúnculos 1-12 mm compr. Capítulos homógamos. Capítulos masculinos 4-7 mm alt.; invólucro 3,3-5,1 × 3,3-9,3 mm, 3-4-seriado; brácteas involucrais externas ovadas, medianas e internas elípticas, ápice agudo, curtamente fimbriado, margens inteiras, escariosa. Flores masculinas 20-60; corola 2,9-3,9 mm compr., tubo $1,7-2,5 \mathrm{~mm}$ compr., fauce $0,5-0,8 \mathrm{~mm}$, lacínias $0,6-0,8 \mathrm{~mm}$ compr.; anteras exsertas; estilete $3,8-4,1 \mathrm{~mm}$ compr.; papilho 3,3-3,8 mm compr., ápice espessado. Capítulos femininos 3,9-7,6 mm alt.; invólucro 3-4,3 × 3-4,3 mm, 3-6-seriado; brácteas involucrais externas ovadas, medianas oblongas, internas estreito-oblongas, ápice inteiro, margens inteiras ou denticuladas, escariosas. Flores femininas $130-543$; corola $1-1,5 \mathrm{~mm}$ compr.; estilete $2,3-3 \mathrm{~mm}$ compr. Cipselas $0,4-0,6 \mathrm{~mm}$ compr., 4-6-costadas, glabras; papilho 2,8-3,3 $\mathrm{mm}$ compr.

Material selecionado: Cabo Frio, 29.XI.1953, A.P. Duarte 3642 (RB). Campos dos Goytacazes, 27.XI.1979, D.S.D. Araújo 3452 (GUA). Duque de Caxias, 4.IV.1967, A. Guinema (SP 99981). Itaguaí, 26.XI.1980, M. Rosa 54 (RBR). Itatiaia, 21.I.1929, P. Campos Porto 1872 (RB). Rio de Janeiro, 27.IV.1959, E. Pereira 4882 (HB). Seropédica, 29.I.1950, H. Monteiro Filho 2848 (RBR). Vassouras, 28.II.1940, H. Monteiro Filho 2208 (RBR); 7.III.1940, H. Monteiro Filho 2267 (RBR). Sem município, Praia do Pinto, 21.II.1918, Dionisio (RB 9005).

Baccharis glutinosa apresenta ampla distribuição nas Américas. Ocorre nos Estados Unidos, Venezuela, Colômbia, Peru, Chile, Bolívia, Paraguai, Brasil, Uruguai e Argentina. No Brasil ocorre nas Regiões Nordeste (BA, PE), Centro-Oeste (MT, MS), Sudeste (MG, RJ, SP) e Sul (PR, SC, RS), nos Biomas Caatinga, Cerrado, Mata Atlântica, Pampa e Pantanal. No estado do Rio de Janeiro (Fig. 2), ocorre desde o nível do mar até altitudes de aproximadamente $800 \mathrm{~m}$, em locais sob influência da Floresta Ombrófila Densa, em habitats abertos sob sol pleno, como brejos, várzeas ou áreas antropizadas nas margens de rodovias. Floresce e frutifica de novembro a fevereiro. Erva-santa (Corrêa 1984).

Hellwig (1993) esclareceu a identidade do nome Bacchans glutinosa, que vinha sendo aplicado equivocadamente aos espécimes de $B$. salicifolia (Ruiz \& Pav.) Pers. Müller (2006) propôs vários sinônimos para $B$. glutinosa, que são aceitos no presente trabalho, entre eles B. medullosa DC., binômio comumente usado no Brasil para se referir à mesma espécie. 


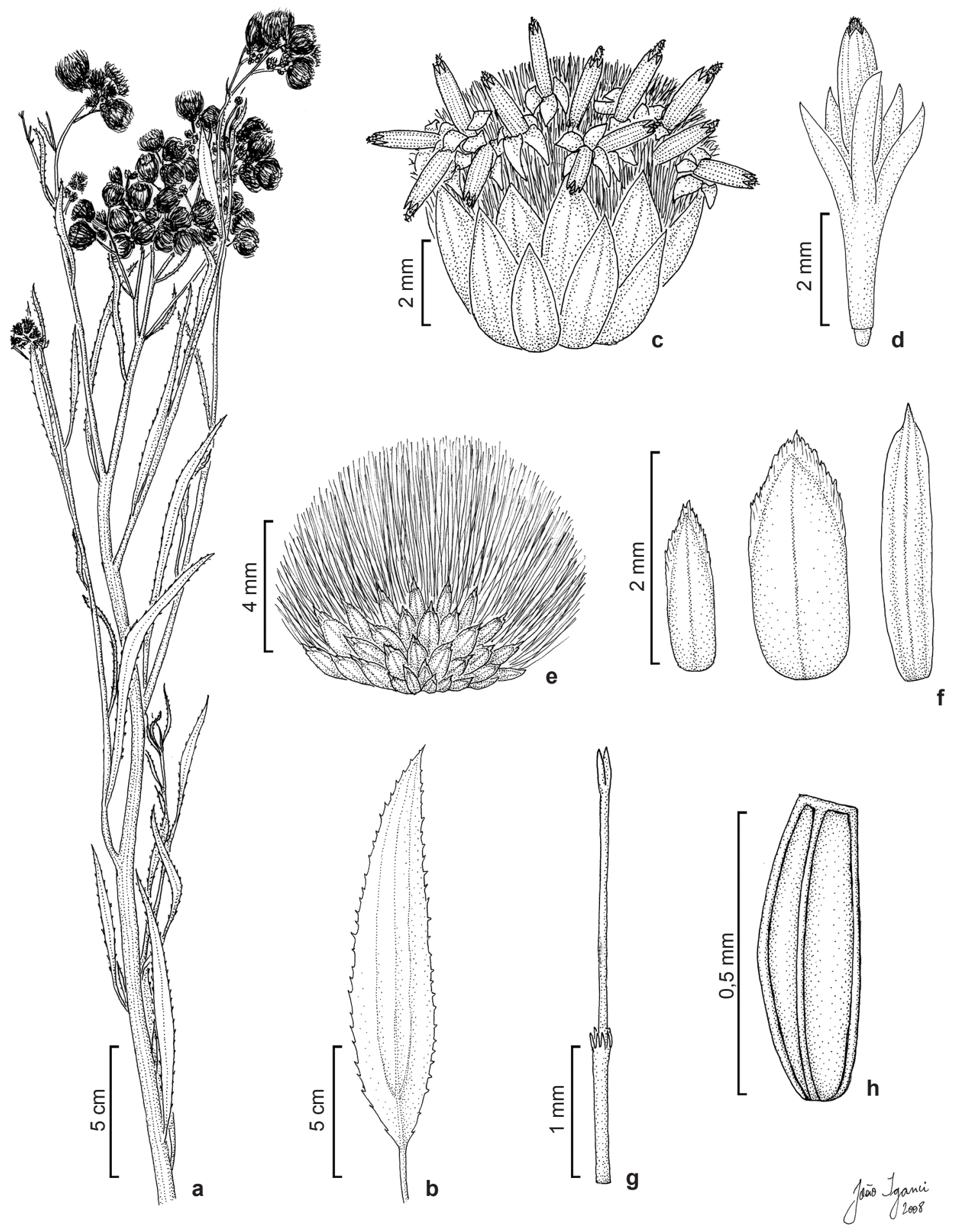

Figura 3 - Baccharis glutinosa Pers.: a. ramo florífero, planta feminina; b. folha; c. capítulo masculino; d. flor masculina (papilho removido); e. capítulo feminino; f. brácteas involucrais das flores femininas; g. corola e estilete da flor feminina; h. cipsela (a, b, e-g: Dionysio 9005; c, d: Campos-Porto 1872).

Figure 3 - Baccharis glutinosa Pers.: a. flowering shoot, female plant; b. leaf; c. male capitulum; d. male floret (pappus removed); e. female capitulum; f. phyllaries; g. corolla and style of female floret; h. cypsela (a, b, e-g: Dionysio 9005; c, d: Campos-Porto 1872). 
3. Baccharis vulneraria Baker in Martius, Fl. bras. 6(3): 75. 1882. Ilustrações: Cabrera (1963, 1974).

Fig. 4

Subarbustos 0,5-2 $\mathrm{m}$ alt., monóicos. Folhas com pecíolo 0,5-2,5 cm compr.; lâmina 2,5-9 × 0,5-4 cm, lanceolada, elíptica a ovada, viscosas, ápice agudo, margens serreadas, base obtusa, 3 nervuras acródromas basais. Panículas $15-35 \times$ 11-24 cm; pedúnculos 1-12 mm compr. Capítulos heterógamos 2,3-4,2 $\mathrm{mm}$ alt.; invólucro 2,3-3,3 $\times 3,3-7,8 \mathrm{~cm}, 2-3$-seriado; brácteas involucrais externas e medianas ovadas, internas ovadas a linear-elípticas, ápice agudo, margens inteiras, escariosa. Flores masculinas 3-6; corola 3-4,2 mm compr., tubo $1,7-2 \mathrm{~mm}$ compr., fauce $0,2-0,3 \mathrm{~mm}$, lacínias $0,5-0,7 \mathrm{~mm}$; anteras inclusas; estilete 2,8 3,4 mm compr.; papilho 3,5-3,8 mm compr., ápice levemente espessado. Flores femininas 70-110; corola 1,5-2,1 mm compr.; estilete 2,1-2,6 mm compr. Cipselas 0,4-0,7 mm compr., 4-6- costadas, papilosas nas costelas; papilho 2,1-2,3 mm compr. Material selecionado: Nova Friburgo, 4.II.1883, $J$. Saldanha 7054 (R). Petrópolis, 19.III.1915, C. Diogo 531 (R). Teresópolis, 2.IV.1917, A.J. Sampaio 2099 (R). Material adicional selecionado: ESPÍRITO SANTO: Castelo, 25.III.2005, L. Kollmann 7563 (HB, MBML). SANTA CATARINA: Nova Teutônia, 15.II.1944, F. Plauman 391 (RB). SÃO PAULO: Campos do Jordão, 8.II.1938, G. Hashimoto 29 (RB).

Baccharis vulneraria apresenta ampla distribuição na porção meridional da América do Sul. Ocorre no Paraguai, Brasil, Uruguai e Argentina. No Brasil é encontrada nas Regiões Sudeste (MG, ES, RJ, SP) e Sul (PR, SC, RS), nos Biomas Mata Atlântica e Pampa. No Rio de Janeiro (Fig. 2), possui registros para a faixa altitudinal entre 600 e $1000 \mathrm{~m}$, vegetando em locais sob influência da Floresta Ombrófila Densa, em bordas de florestas ou em habitats abertos sob sol pleno, como brejos, várzeas ou áreas antropizadas. Floresce e frutifica de fevereiro a abril. Erva-desant'ana (Velloso 303).

Baccharis vulneraria possui folhas viscosas e com morfologia semelhante à $B$. serrulata Pers. (sect. Molinae), ocorrendo em habitats similares, como bordas de florestas e áreas antropizadas. Pode ser diferenciada devido aos capítulos heterógamos (vs. capítulos homógamos). Primeira citação para os estados do Rio de Janeiro e Espírito Santo, anteriormente referida apenas para São Paulo, Minas Gerais e Região Sul. Baccharis vulneraria é o nome correto para a espécie, embora o uso do sinônimo Baccharidastrum triplinervium (Less.)
Cabrera seja comum na literatura e em herbários (Heiden 2009).

\section{Baccharis subgen. Molina sect. Caulopterae} DC., Prodr. 5: 424. 1836.

A seção Caulopterae corresponde aos Grupos Organensis e Trimera de Barroso (1976) e ao Grupo Baccharis genistelloides de Müller (2006). A seção é exclusiva da América do Sul e compreende 35 espécies, das quais 29 ocorrem no Brasil (Heiden et al. 2009b). As montanhas e planaltos das Regiões Sul e Sudeste do Brasil e os Andes desde a Colômbia até a Argentina são os principais centros de diversidade do grupo (Müller 2006; Heiden et al. 2007). No Rio de Janeiro estão representadas oito espécies, com ocorrência em restingas, bordas de florestas e campos de altitude, sendo muitas vezes freqüentes em locais antropizados em áreas de Floresta Ombrófila Densa Montana. Algumas espécies, conhecidas popularmente como carqueja, são consideradas medicinais, sendo comumente comercializadas e ocasionalmente cultivadas em quintais.

As espécies ocorrentes no Rio de Janeiro são caracterizadas pelo caule cilíndrico, geralmente alado ou estriado, folhas desenvolvidas ou escamiformes, com ambas as faces aparentemente glabras; racemos ou panículas de ramos espiciformes; capítulos femininos com clinanto revestido por tricomas bisseriados glandulares; corola das flores femininas destituída de uma coroa subapical de tricomas; e cipselas glabras, com com papilho unisseriado, não acrescente e cerdas espessadas na base e fundidas formando um anel.

4. Baccharis altimontana G.Heiden, Baumgratz \& Esteves, J. Bot. Res. Inst. Texas 3 (1): 140. 2009. Ilustração: Heiden et al. (2009a).

Subarbustos 0,2-0,4 m alt., ramos eretopatentes ou prostrados. Caule e ramos 3-alados, alas $0,5-6,5 \times 0,3-1,6 \mathrm{~cm}$, aplanadas ou onduladas, fortemente resinosas, aparentemente glabras. Folhas $0,3-2 \times 0,2-0,5 \mathrm{~mm}$, escamiformes, triangulares. Ramos espiciformes $3-18 \mathrm{~cm}$; capítulos solitários ou 2-3, esparsos ao longo do eixo, espiga principal excedendo as espigas axilares em comprimento. Capítulos masculinos $4-5,5 \mathrm{~mm}$ alt., invólucro 4,4-6,5 × 4-6,8 $\mathrm{mm}, 6-8$-seriado, urceolado a campanulado; brácteas involucrais externas e medianas ovadas, internas ovadas a elípticas, ápice agudo, inteiro ou denteado, margens denteadas, escariosas. 


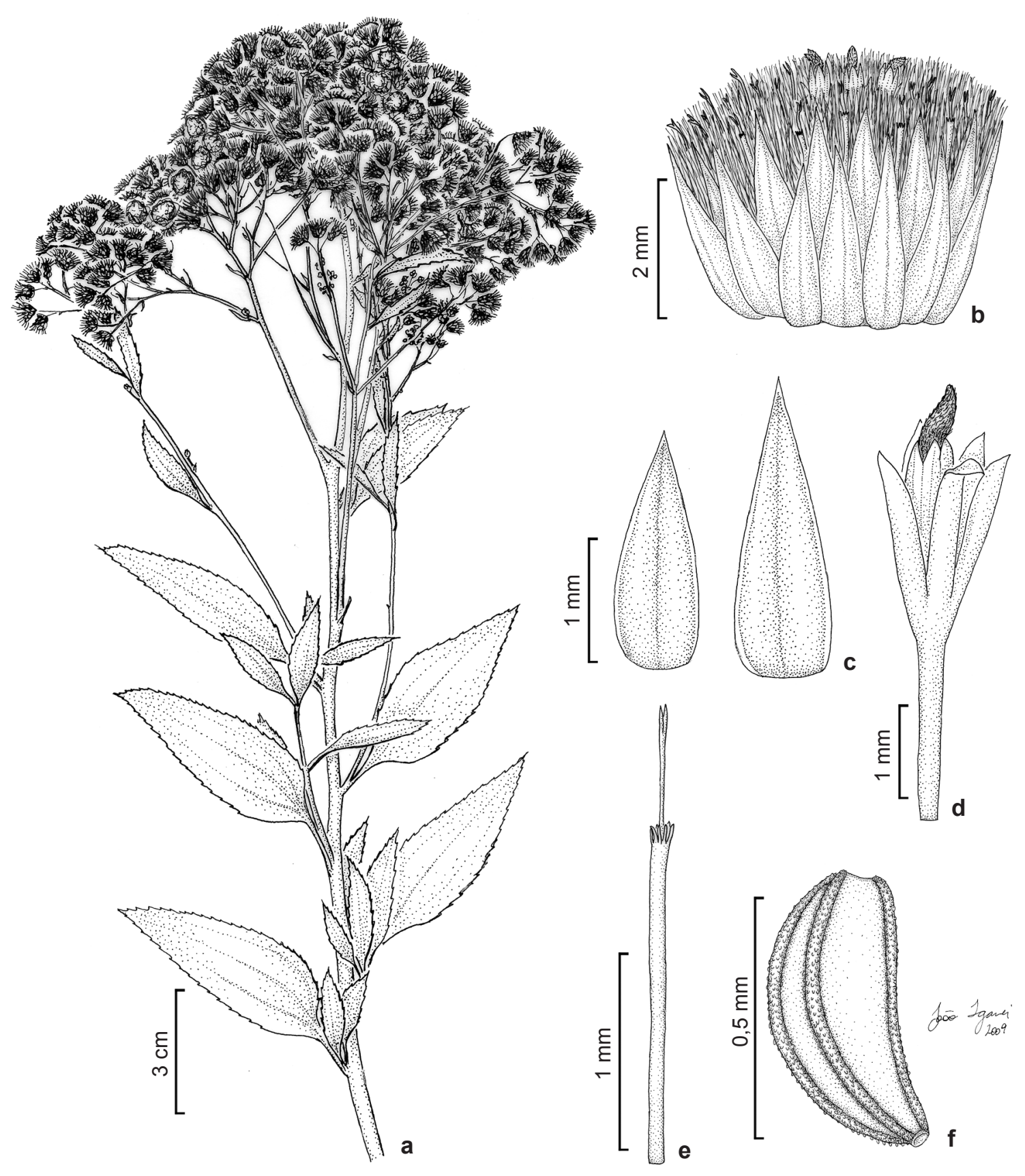

Figura 4 - Baccharis vulneraria Baker: a. ramo florífero; b. capítulo; c. brácteas involucrais; d. flor masculina (ovário vestigial e papilho removidos); e. corola e estilete da flor feminina; f. cipsela (a, b: Smith 10285; c-f: Hashimoto 29). Figure 4 - Baccharis vulneraria Baker: a. flowering shoot; b. capitulum; c. phyllaries; d. male floret (pappus and vestigial ovary removed); e. corolla and style of female floret; f. cypsela (a, b: Smith 10285; c-f: Hashimoto 29). 
Flores masculinas 35-63; corola 2,9-4 mm compr., tubo $1,8-2,5 \mathrm{~mm}$ compr., fauce $0,2-0,4$ mm compr., lacínias 1-1,4 mm compr.; estilete 3,2-4 mm compr.; papilho 3,2-4,2 mm compr., ápice levemente espessado. Capítulos femininos 6,5-8 mm alt.; invólucro 4,4-6,5 × 4-6,8 mm, 8-10-seriado, urceolado a campanulado; brácteas involucrais externas e medianas ovadas, internas ovadas a elípticas, ápice agudo, inteiro ou denteado, margens denteadas, escariosas. Flores femininas 34-42; corola 2,5-3,4 mm compr., ápice liguliforme, 3-5 dentículos irregulares; estilete 3,1-5,1 mm compr. Cipselas 1,2-1,5 mm compr., 16-22-costadas, glabras; papilho 4-4,7 $\mathrm{mm}$ compr.

Material selecionado: Itatiaia, 5.XII.1964, M.C. Vianna 207 (GUA, RB). Nova Friburgo, 22.III.2008, G. Heiden 711 (K, RB). Teresópolis, 26.IX.2007, G. Heiden 879, 880 (RB).

Baccharis altimontana apresenta distribuição exclusiva no Brasil, na Região Sudeste (MG, RJ, SP), com ocorrência no Bioma Mata Atlântica. No Rio de Janeiro (Fig. 5) ocorre em altitudes acima de $1900 \mathrm{~m}$, no maciço do Itatiaia (Serra da Mantiqueira), na Serra dos Órgãos e no Pico da Caledônia (Serra do Mar). Forma populações esparsas, com indivíduos ereto-patentes ou prostrados em fendas de afloramentos rochosos nos campos de altitude, onde ocorre em locais com umidade constante. Floresce e frutifica entre novembro e abril. Carqueja (Ribeiro 138; Heiden 994).

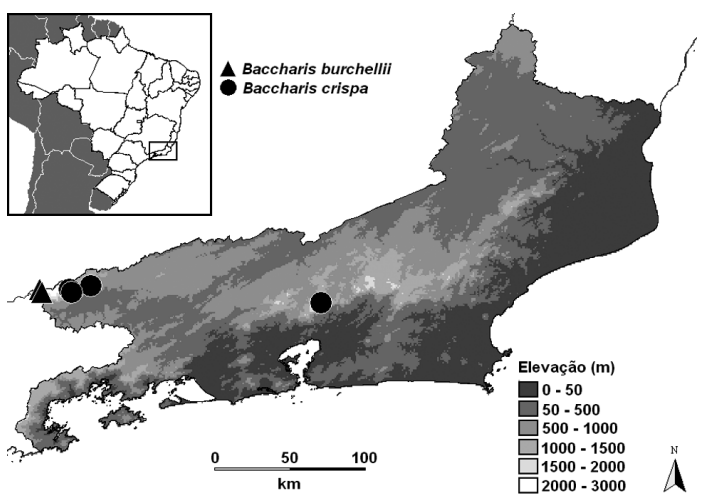

Figura 5 - Distribuição geográfica de Baccharis altimontana Heiden, Baumgratz \& Esteves (ם), B. burchellii Baker $(\boldsymbol{\Delta})$ e B. crispa Spreng. (•) no estado do Rio de Janeiro.

Figure 5 - Geographic distribution of Baccharis altimontana Heiden, Baumgratz \& Esteves $(\mathbf{\square})$, B. burchellii Baker ( $\mathbf{A})$ and B. crispa Spreng. (•) in Rio de Janeiro state, Brazil.
Heiden et al. (2009a) ao descreverem Baccharis altimontana a relacionam com espécies do Complexo Baccharis genistelloides. No estado do Rio de Janeiro, B. altimontana pode ser diferenciada de $B$. crispa pelos ramos ereto-patentes ou prostrados e corola da flor feminina liguliforme, e de B. myriocephala pelo porte $0,2-0,4 \mathrm{~m}$ alt., panículas $18-24 \mathrm{~cm}$ compr., com ramos espiciformes $3-18 \mathrm{~cm}$ compr., e capítulo feminino com invólucro urceolado a campanulado.

5. Baccharis burchellii Baker in Martius, Fl. bras. 6(3): 44. 1882. Ilustração: Malagarriga (1976).

Fig. 6

Arbustos 1-3 m alt., eretos. Caule e ramos 3 -alados, alas 0,5-5 ×0,1-0,3 cm, aplanadas, resinosas. Folhas desenvolvidas, sésseis, lâmina 1,3-3,7 × 0,3-1 cm, coriácea, elípticas a lanceoladas, ápice agudo, margens inteiras, revolutas, base atenuada; uninérveas, peninérveas ou actinódromas 1-4 mm suprabasais; face abaxial cinérea, face adaxial resinosa, brilhosa, glabrescentes. Panículas 1,8-12 × 1,4-8,1 $\mathrm{cm}$, piramidais, terminais; ramos espiciformes $0,5-5$ cm compr.; capítulos sésseis ou pedúnculo $0,1-3 \mathrm{~mm}$ compr. Capítulo masculino 2,4-4 mm alt.; invólucro 2-3,2 × 2,2-4 mm, 3-4-seriado, campanulado; brácteas involucrais externas e medianas ovadas, internas elípticas, ápice curtamente fimbriado, margens denteadas, estreitamente escariosa. Flores masculinas 20-28; corola 2,1-2,7 mm compr., tubo $1-1,4 \mathrm{~mm}$ compr., fauce $0,2-0,5 \mathrm{~mm}$ compr., lacínias 0,6-1 mm compr.; estilete 2,4-3 mm compr;; papilho 1,8-2,1 mm compr., ápice levemente espessado. Capítulo feminino 3,1-4,9 mm alt.; invólucro 2,4-3,8 $\times 2-4,3 \mathrm{~mm}, 4-5$-seriado, cilíndrico a campanulado; brácteas involucrais externas e medianas ovadas, internas elípticas, ápice denteado, margens inteiras, estreitamente escariosas. Flores femininas 16-30; corola 1,8-2,2 mm compr., ápice 5-denticulado; estilete 2,1-2,4 mm compr. Cipselas 0,6-0,8 mm compr., 5-8-costadas, papilosas nas costelas, papilho 2,4-2,7 $\mathrm{mm}$ compr.

Material examinado: Itatiaia, IX.1934, A.C. Brade 14049 (RB); 14.XII.2004, R.C. Forzza 3727 (RB); 12.IX.2007, G. Heiden 816(RB); 17.XII.2007, G. Heiden 926 (RB).

Material adicional selecionado: MINAS GERAIS: Poços de Caldas, 6.XI.1940, H.L. Mello-Barreto 10966 (RB).

Baccharis burchellii apresenta distribuição exclusiva no Brasil, sendo endêmica da Região Sudeste (MG, RJ, SP), com ocorrência no Bioma Mata Atlântica. No estado do Rio de Janeiro 

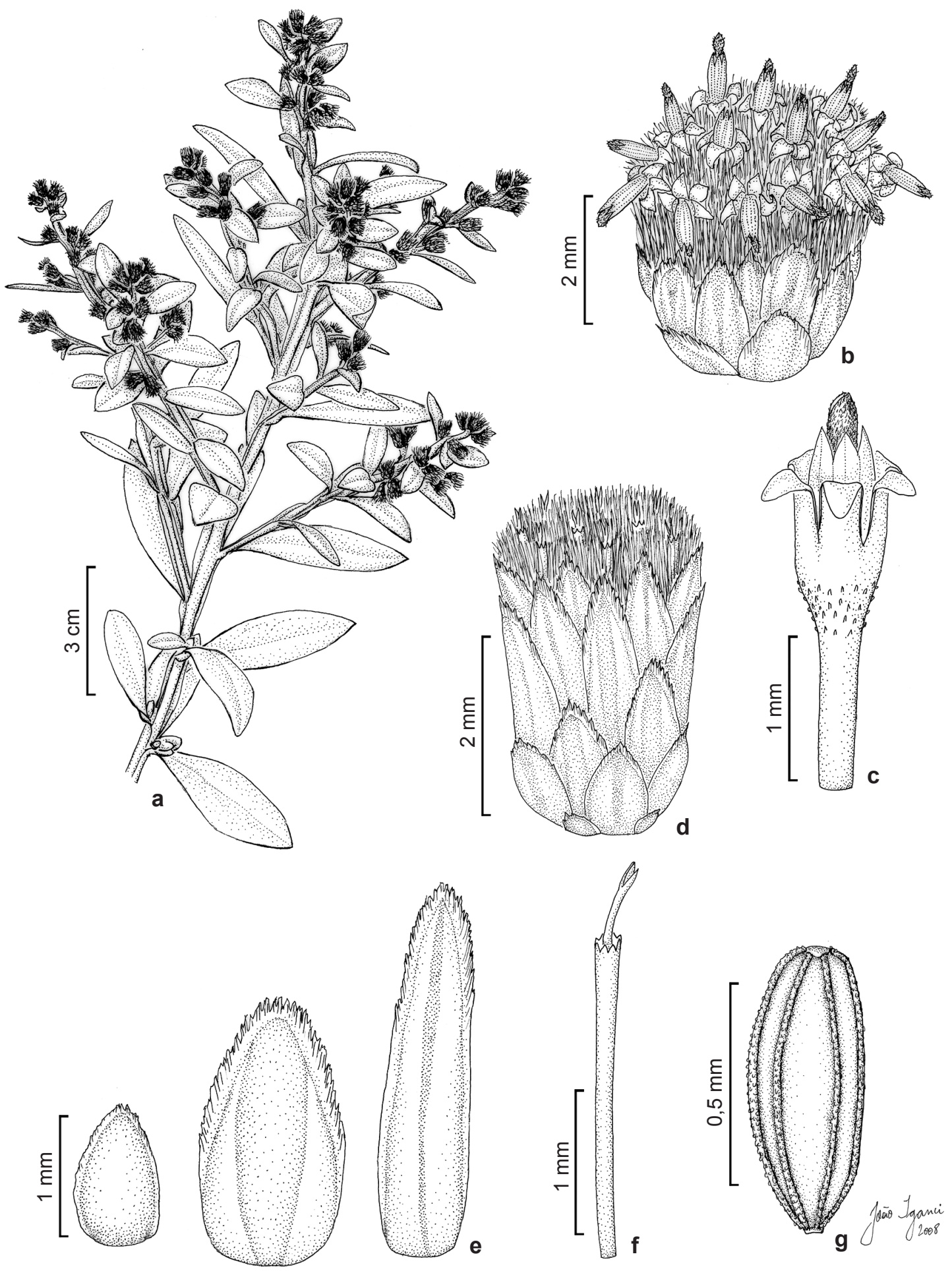

Figura 6-Baccharis burchellii Baker: a. ramo florífero, planta feminina; b. capítulo masculino; c. flor masculina (ovário vestigial e papilho removidos); d. capítulo feminino; e. brácteas involucrais do capítulo feminino; f. corola e estilete da flor feminina; g. cipsela (a: Heiden 816; b, c: Mello-Barreto 10966; d-g: Forzza 3727).

Figure 6-Baccharis burchellii Baker: a. flowering shoot, female plant; b. male capitulum; c. male floret (pappus and vestigial ovary removed); $d$. female capitulum; e. phyllaries of female capitulum; f. corolla and style of female floret; g. cypsela (a: Heiden 816; b, c: Mello-Barreto 10966; d-g: Forzza 3727). 
(Fig. 5) medra acima de $2000 \mathrm{~m}$ de altitude, restrita aos campos de altitude do maciço do Itatiaia, na Serra da Mantiqueira. Populações esparsas ocorrem em afloramentos rochosos e locais com solo raso sob sol pleno. Floresce e frutifica entre setembro e dezembro. Alecrim-carqueja (Heiden 926).

Baccharis burchellii é semelhante a $B$. regnelli, mas pode ser diferenciada pelo caule alado, folhas sésseis, margens inteiras, e panículas menores $(4-16 \times 2-10 \mathrm{~cm})$. Primeira citação para o estado do Rio de Janeiro, pois até então era conhecida apenas para São Paulo e Minas Gerais.

6. Baccharis crispa Spreng., Syst. Veg. ed. 16, 3: 466. 1826. Molina crispa (Spreng.) Less., Linnaea 6: 141. 1831. Baccharis genistelloides var. crispa (Spreng.) Baker in Martius, Fl. bras. 6(3): 41. 1882. Pingraea crispa (Spreng.) F.H.Hellw., Candollea 46: 217. 1993. Baccharis genistelloides subsp. crispa (Spreng.) Joch.Müll., Syst. Bot. Monogr. 76: 198. 2006. Ilustrações: Baker (1882); Ariza (1973); Barroso (1976); Malagarriga (1976); Cabrera (1963, 1974, 1978); Diesel (1987); Soria (1993); Müller (2006); Heiden et al. (2009b). $\quad$ Fig. 7

Subarbustos $0,15-1 \mathrm{~m}$ alt., eretos. Caule e ramos 3-alados, alas $1-7 \times 0,1-1,3 \mathrm{~cm}$, aplanadas ou onduladas, resinosas, aparentemente glabras. Folhas $1-5 \times 1-2,5 \mathrm{~mm}$, escamiformes. Panículas $15-40 \mathrm{~cm}$ compr.; ramos espiciformes 3-20 cm compr., densos ou laxos, às vezes reduzidos a capítulos solitários ou glomérulos com 2-5 capítulos. Capítulo masculino 4,3-5,5 mm alt.; invólucro 3,2-4,2 × 3,3-6,3 mm, 4-6-seriado, campanulado; brácteas involucrais externas ovadas a oblongas, medianas elípticas a ovadas, internas elípticas, ápice denteado, margens denteadas ou inteiras, estreitamente escariosa. Flores masculinas 16-28; corola 3-4,2 mm compr., tubo $1,7-2,5 \mathrm{~mm}$ compr., fauce $0,2-0,8 \mathrm{~mm}$ compr., lacínias 1-1,5 mm compr.; estilete 3-4,5 mm compr.; papilho 3-5 mm compr., ápice levemente espessado. Capítulo feminino 4,6-7,2 $\mathrm{mm}$ alt.; invólucro 4-6,6 × 3,2-4,3 mm, 4-7-seriado, cilíndrico a campanulado; brácteas involucrais externas ovadas a oblongas, medianas elípticas a ovadas, internas elípticas, ápice denticulado, margens inteiras ou denticuladas, curtamente escariosas. Flores femininas 23-28; corola 2,7-4,3 mm compr., ápice truncado ou irregularmente denticulado; estilete 3,6-4,5 mm compr. Cipselas 1-1,5 mm compr., 8-12-costadas, glabras; papilho 2,8-4,5 mm compr. Material selecionado: Itatiaia, III.1894, E. Ule 177 (R). Resende, IX.2007, G. Heiden 833, 834 (RB). Teresópolis, 27.IX.2007, G. Heiden 902, 903 (RB).
Material adicional selecionado: RIO GRANDE DO SUL: São Lourenço do Sul, III.2006, G. Heiden 648, 649 (RB).

Baccharis crispa apresenta ampla distribuição na América do Sul, ocorrendo no Peru (Müller 2006), Bolívia, Paraguai, Brasil, Uruguai e Argentina. No Brasil é encontrada nas Regiões Sudeste (MG, RJ, SP) e Sul (PR, SC, RS), nos Biomas Cerrado, Mata Atlântica e Pampa. No Rio de Janeiro (Fig. 5) ocorre em altitudes superiores a $2000 \mathrm{~m}$, no maciço do Itatiaia (Serra da Mantiqueira), e no maciço da Serra dos Órgãos (Serra do Mar). Forma populações esparsas ou densas em campos de altitude, onde predominam gramíneas baixas, sendo encontrada sempre em habitats abertos, ensolarados, próximo a áreas úmidas, como brejos e vertentes, e mais raramente em campos secos e afloramentos rochosos. Floresce de dezembro a março, com dispersão das cipselas até maio. Carqueja (Heiden 833).

Baccharis crispa possui distribuição ampla no Brasil, sendo freqüentemente referida pelos sinônimos $B$. trimera (Less.) DC. ou B. cylindrica (Less.) DC (Heiden et al. 2009b). A espécie é geralmente confundida com B. myriocephala, táxon próximo morfologicamente e também comumente tratado sob o nome B. trimera. Baccharis crispa apresenta hábito ereto, panículas $15-40 \mathrm{~cm}$ compr., com ramos espiciformes 3-20 cm compr., corola feminina com ápice truncado ou irregularmente denticulado e cipselas $1-1,5 \mathrm{~mm}$ compr., 8-12-costadas, enquanto que B. myriocephala se caracteriza pelo hábito apoiante ou decumbente, panículas $25-80 \mathrm{~cm}$ compr., com ramos espiciformes 10-35 cm compr., corola feminina liguliforme e cipselas $0,6-1 \mathrm{~mm}$ compr., 12-20-costadas. Estes táxons podem ocorrer em simpatria, porém ocupando nichos ecológicos distintos. Enquanto $B$. crispa é um subarbusto heliófilo e exclusivo de vegetação campestre, B. myriocephala ocorre preferencialmente como um arbusto apoiante, às vezes epífito, em bordas e interior de matas, ou em encostas úmidas e sombreadas, e quando raramente ocorre em áreas abertas e ensolaradas, apresenta-se como subarbusto, com ramos decumbentes.

7. Baccharis glaziovii Baker in Martius, Fl. bras. 6(3): 44. 1836. Ilustrações: Malagarriga (1976); Heiden et al. (2009b).

Fig. 8

Arbustos 0,5-2,5 m alt., eretos ou apoiantes. Caule e ramos 3-alados, alas $1-19 \times 0,5-1,3 \mathrm{~cm}$, aplanadas ou levemente onduladas, levemente resinosas; alas e folhas aparentemente glabras. 


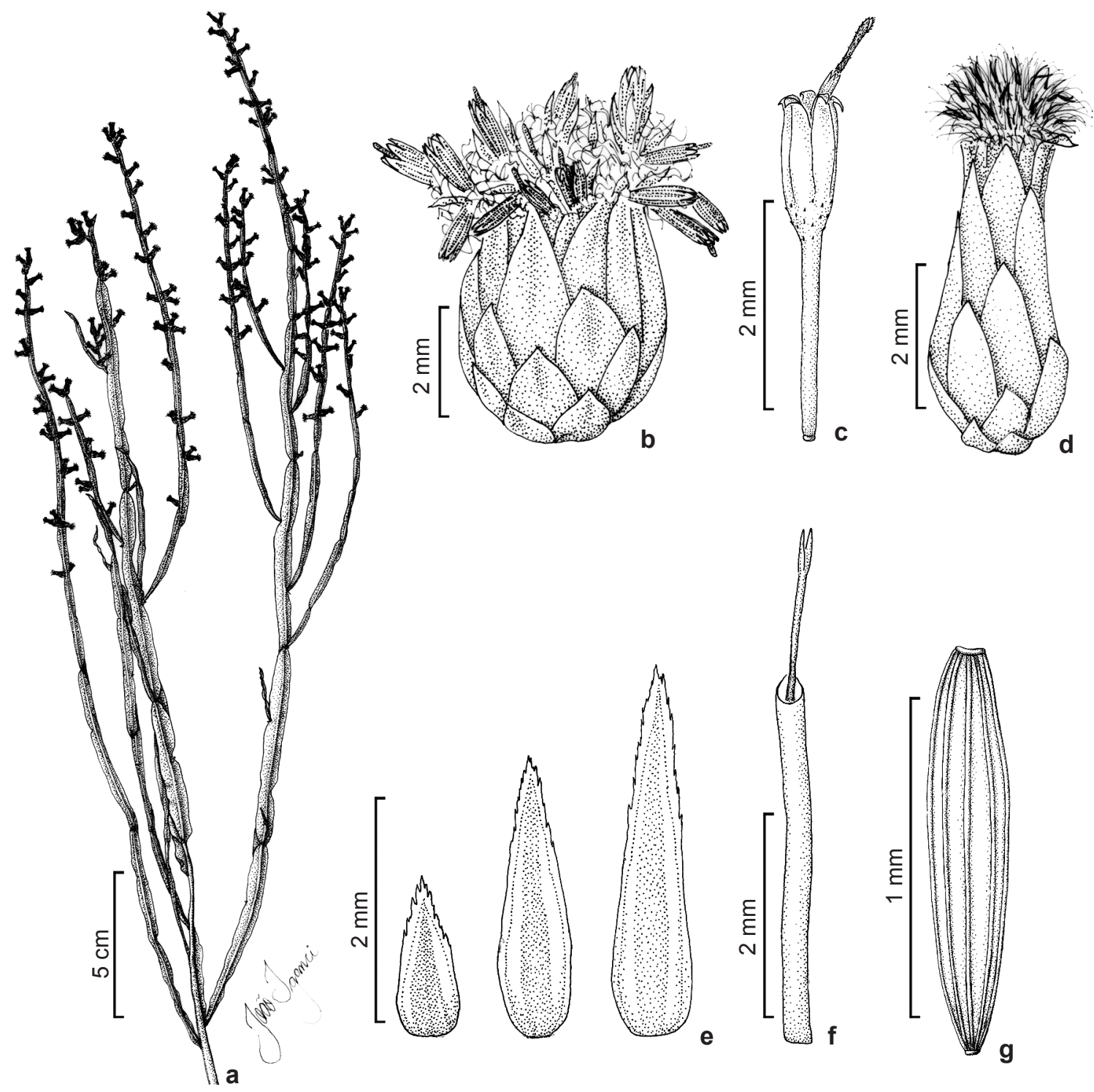

Figura 7 - Baccharis crispa Spreng.: a. ramo florífero, planta feminina; b. capítulo masculino; c. flor masculina (papilho removido); d. capítulo feminino; e. brácteas involucrais do capítulo feminino; f. corola e estilete da flor feminina; g. cipsela (a, d: Heiden 648; b: Heiden 834; c: Heiden 649; e-g: Heiden 833).

Figure 7 - Baccharis crispa Spreng.: a. flowering shoot, female plant; b. male capitulum; c. male floret (pappus removed); d. female capitulum; e. phyllaries of female capitulum; f. corolla and style of female floret; g. cypsela (a, d: Heiden 648; b: Heiden 834; c: Heiden 649; e-g: Heiden 833).

Folhas $0,1-6 \times 0,1-2,7 \mathrm{~cm}$, desenvolvidas, subsésseis; lâmina papirácea, oblonga a ovada, ápice obtuso a agudo, margens inteiras, revolutas, base cuneada a arredondada; peninérvea. Panículas 7-17 × 3-7,5 cm, piramidais; ramos espiciformes $1-4 \mathrm{~cm}$ compr.; brácteas foliáceas ou escamiformes. Capítulo masculino 3,2-4,8 mm alt., invólucro 2,9-3,7 × 2,7-5 mm, 3-4-seriado, oblongo a campanulado; brácteas involucrais externas ovadas a oblongas, medianas elípticas a ovadas, internas elípticas, ápice denteado a fimbriado, margens denteadas, escariosas. Flores masculinas 12-25; corola 2,4-3 mm compr., tubo $1,2-1,5 \mathrm{~mm}$ compr., fauce $0,1-0,3 \mathrm{~mm}$ compr., lacínias $0,5-0,8 \mathrm{~mm}$ compr.; estilete $2,4-3,1$ mm compr.; papilho 2,4-3,2 mm compr., ápice 

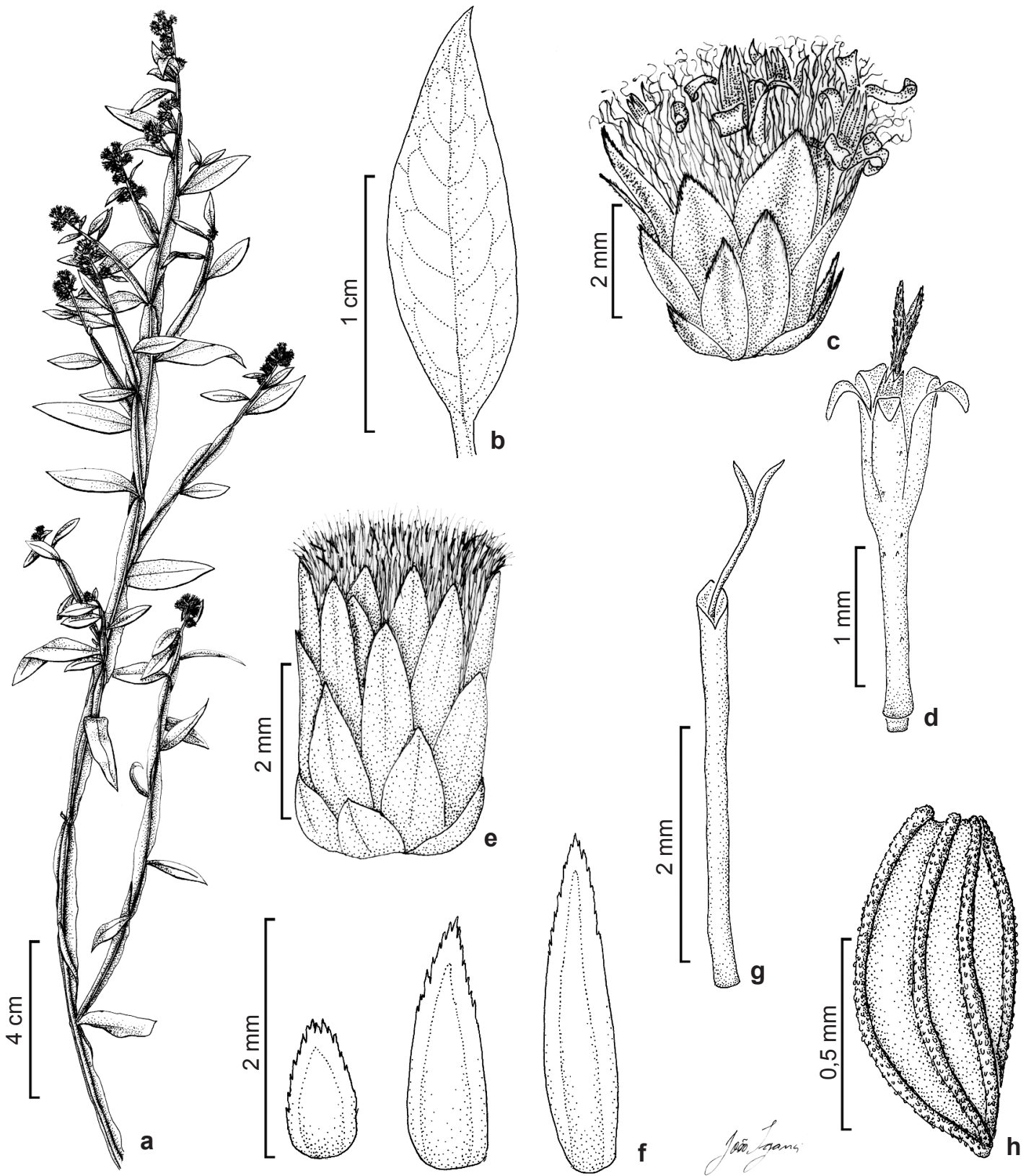

Figura 8 - Baccharis glaziovii Baker: a. ramo florífero, planta feminina; b. folha; c. capítulo masculino; d. flor masculina (papilho removido); e. capítulo feminino; f. brácteas involucrais do capítulo feminino; g. corola e estilete da flor feminina; h. cipsela (a, b, e: Pereira 7115; c: Heiden 569; d: Heiden 801; f, g: Heiden 800 h: Eiten 6677).

Figure 8 - Baccharis glaziovii Baker: a. flowering shoot, female plant; b. leaf; c. male capitulum; d. male floret (pappus removed); e. female capitulum; f. phyllaries of female capitulum; g. corolla and style of female floret; h. cypsela (a, b, e: Pereira 7115; c: Heiden 569; d: Heiden 801; f, g: Heiden 800 h: Eiten 6677).

não espessado. Capítulo feminino 4,3-5,6 mm alt.; invólucro 4-5 × 3,3-4,9 mm, 5-6-seriado, oblongo a campanulado; brácteas involucrais externas ovadas, medianas ovadas, internas elípticas, ápice denteado a curtamente fimbriado, margens denteadas no ápice, escariosas. Flores femininas 35-52; corola 2,5-3 mm compr., ápice inteiro; estilete 2,7-3,3 mm compr. Cipselas 0,5-0,8 mm compr., 5-7-costadas, papilosas; papilho $3-3,5 \mathrm{~mm}$ compr. 
Material selecionado: Itatiaia, 7.IX.1962, E. Pereira 7115 (HB, PEL). Parati, III.2007, G. Heiden 726 (RB). Resende, 6.XI.1965, G. Eiten 6677 (RB); 12.IX.2007, G. Heiden 800, 801 (K, R, RB, SP)., X.1872, A.F.M. Glaziou 4838 (K, foto!).

Material adicional selecionado: PARANÁ: São Mateus do Sul, 5.XI.2005, G. Heiden 569 (RB).

Baccharis glaziovii ocorre no leste do Paraguai, Brasil e nordeste da Argentina. No Brasil ocorre nas Regiões Sudeste (MG, RJ, SP) e Sul (PR, SC, RS), no Bioma Mata Atlântica. No estado do Rio de Janeiro (Fig. 9) é encontrada em altitudes entre 1500 e 2200 m, no maciço do Itatiaia, na Serra da Mantiqueira, e na Serra da Bocaina (Serra do Mar). Forma populações esparsas, com indivíduos arbustivos apoiantes, em ambientes sombreados nas bordas de florestas altimontanas, ou densas, com espécimes arbustivos eretos em bordas de matas nebulares e em campos de altitude, onde prefere locais úmidos, como brejos e vertentes, ou encostas. Floresce de junho a março, com pico de floração entre setembro e dezembro. Carquejaarbustinho (Heiden 849).

B. glaziovii ocasionalmente é confundida com B. junciformis, mas se distingue pelo hábito arbustivo, folhas com base cuneada ou arredondada e panículas com ramos espiciformes curtos (1-4 cm compr.).

8. Baccharis junciformis DC., Prodr. 5: 426.1836. Molina juncea Less. in Linnaea 6: 145. 1831, non Baccharis juncea (Cass.) Desf., 1829. Ilustrações: Teodoro (1949); Malagarriga (1976); Heiden et al. (2009b).

Fig. 10

Subarbustos 0,5-1,5 m alt., eretos. Caule e ramos com ápice avermelhado, 3-alados, alas 3,5-8 × 0,5-1,5 cm, aplanadas, venulosas, resinosas, aparentemente glabras. Folhas 1,5-6 $\times$ 0,3-2 cm, desenvolvidas, subsésseis, lâmina membranácea ou cartácea, oblonga a ovada nos ramos basais jovens, ovada, às vezes triangular, nos ramos repdrodutivos, ápice obtuso a agudo, margens inteiras, revoluta, base cordada; nervação actinódroma. Panículas 8-30 × 3-15 cm; ramos espiciformes, 5-20 cm compr., às vezes reduzidos a glomérulos 3-7 capítulos, ou a capítulos solitários, subtendidos por bráctea foliácea. Capítulo masculino 4-5,5 mm alt.; invólucro 4-4,8 × 2,9-4,8 mm, 4-5-seriado, cilíndrico a campanulado; brácteas involucrais externas ovadas, medianas ovadas a elípticas, internas elípticas, margens denticuladas, escariosas. Flores

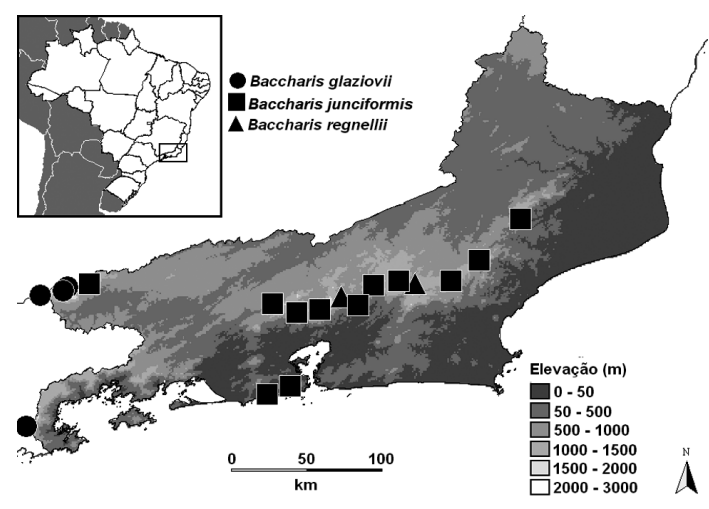

Figura 9 - Distribuição geográfica de Baccharis glaziovii Baker (•), B. junciformis DC. (ロ) e B. regnellii Sch.Bip. ex Baker ( $\boldsymbol{\Delta})$ no estado do Rio de Janeiro.

Figure 9-Geographic distribution of Baccharis glaziovii Baker (•), B. junciformis DC. (ם) and B. regnellii Sch.Bip. ex Baker (A) in Rio de Janeiro state, Brazil.

masculinas 20-33; corola 3,5-4,3 $\mathrm{mm}$ compr., tubo $2,7-3,5 \mathrm{~mm}$ compr., fauce $0-0,1 \mathrm{~mm}$ compr., lacínias 0,8-1,2 $\mathrm{mm}$ compr.; anteras exsertas; estilete 3,5-4,5 mm compr.; papilho 3,8-4,4 mm compr., ápice não espessado. Capítulo feminino 5-6,5 mm alt.; invólucro 4-5,4 × 3-5,1 mm, 5-7-seriado, cilíndrico a campanulado; brácteas involucrais externas obtusas, medianas ovadas, internas elípticas a lineares, margens denticuladas, escariosas. Flores femininas 47-70; corola 3,1-4,5 $\mathrm{mm}$ compr.; ápice liguliforme, irregularmente denteado ou truncado; estilete 4-4,8 $\mathrm{mm}$ compr. Cipselas 1-1,5 mm compr., 5-6-costadas, glabras; papilho 3,5-4 $\mathrm{mm}$ compr.

Material selecionado: Miguel Pereira, 18.IV.2007, G. Heiden 728 (JE, K, R, RB, RBR, SP). Nova Friburgo, 21.III.2007, G. Heiden 707 (K, R, RB, RBR, SP). Petrópolis, 24.III.1879, J. Saldanha 5263 (R). Resende, 28.III.1987, R. Pineschi 152 (GUA). Rio de Janeiro, 12.IV.1973, D. Sucre 9946 (RB). Santa Maria Madalena, 15.V.2007, G. Heiden 748, 749 (RB). Teresópolis, 4.IV.1970, D. Sucre 6502 (RB). Vassouras, 27.II.1940, H. Monteiro Filho 2188 (RBR).

Material adicional selecionado: Capão do Leão, 15.XII.2003, G. Heiden 374 (PEL). São Leopoldo, 23.IV.1937, J. Dutra 1563 (PACA). São Lourenço do Sul, 26.XII.2006, G. Heiden 679 (RB).

Baccharis junciformis apresenta distribuição restrita ao Brasil. Ocorre nas Regiões Sudeste (ES, MG, RJ, SP) e Sul (PR, SC, RS), nos Biomas Mata Atlântica e Pampa. No Rio de Janeiro (Fig. 9) ocorre desde o nível do mar até altitudes de aproximadamente $1000 \mathrm{~m}$, vegetando em locais 


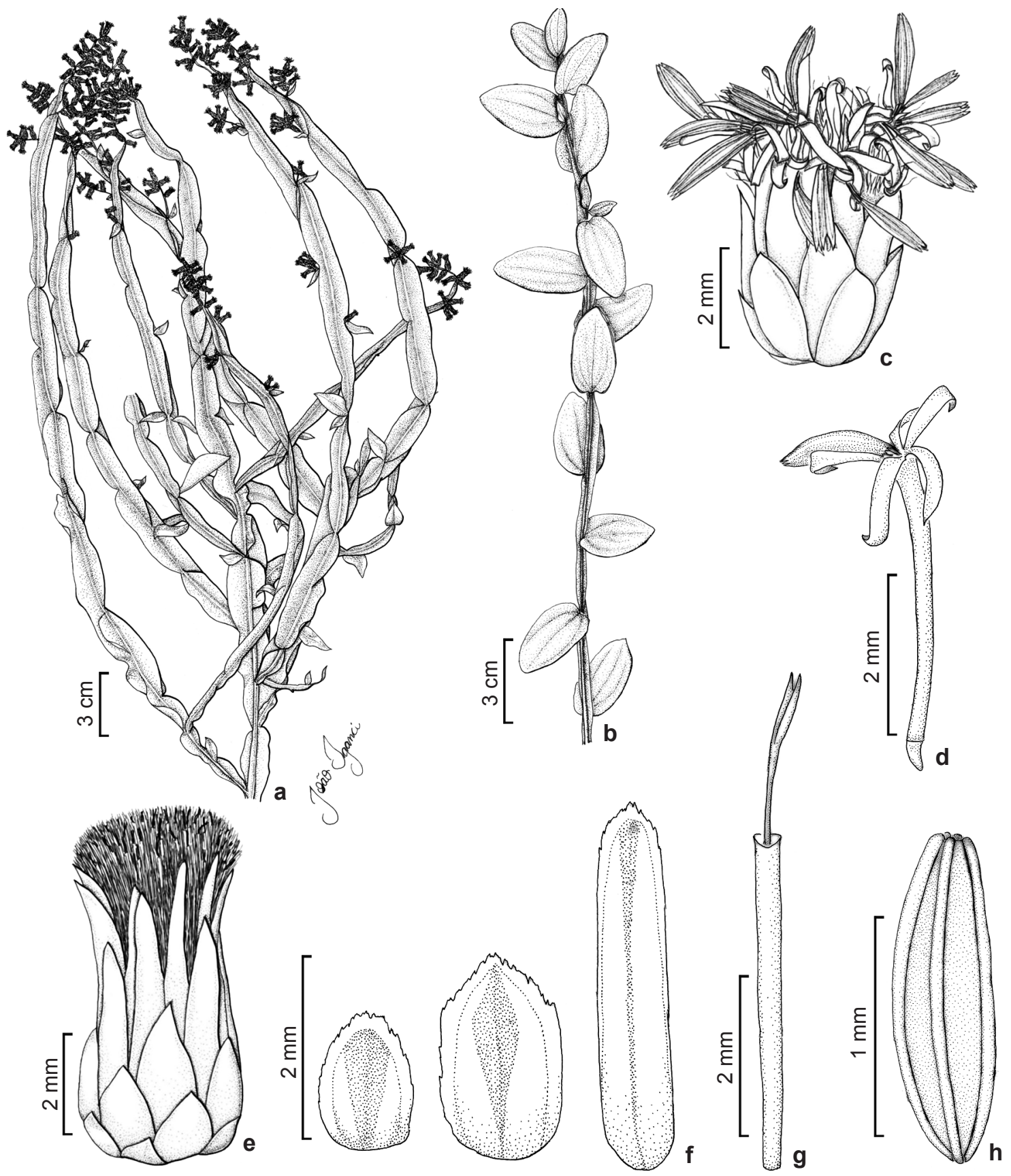

Figura 10 - Baccharis junciformis DC.: a. ramo florífero, planta feminina; b. ramo jovem basal; c. capítulo masculino; d. flor masculina (papilho removido); e. capítulo feminino; f. brácteas involucrais do capítulo feminino; g. corola e estilete da flor feminina; h. cipsela (a, e, g: Heiden 374; b: Heiden 679; c, d: Dutra 1563; f, h: Heiden \& Baumgratz 748). Figure 10 - Baccharis junciformis DC.: a. flowering shoot, female plant; b. young basal shoot; c. male capitulum; d. male floret (pappus removed); e. female capitulum; f. phyllaries of female capitulum; g. corolla and style of female floret; h. Cipsela (a, e, g: Heiden 374; b: Heiden 679; c, d: Dutra 1563; f, h: Heiden \& Baumgratz 748). 
úmidos e ensolarados, como brejos e várzeas de rios, em locais sob influência da Floresta Ombrófila Densa, e em brejos e margens de lagoas, nas restingas. Floresce e frutifica entre janeiro e maio, com pico de floração entre março e abril. Carquejado-brejo (Heiden 728; Santos 230), carqueja-doce (Santos 116).

Baccharis junciformis é uma espécie polimórfica, porém de fácil reconhecimento em campo devido ao hábito subarbustivo, caule alado, venuloso, ápice dos ramos com coloração avermelhada e limbo foliar desenvolvido. Os ramos jovens basais são muito distintos dos ramos reprodutivos, apresentando alas estreitas e limbo foliar oblongo ou ovalado de maiores dimensões (Fig. 21 B). Heiden et al. (2009b) esclareceram a identidade de $B$. junciformis e reconheceram $B$. junciformis var. triptera Baker, $B$. trimeroides Malme, B. cordata L.Teodoro e B. usterii Heering, este último com uso ainda corrente, como sinônimos dessa espécie.

9. Baccharis myriocephala DC., Prodr. 5: 426. 1836. Ilustrações: Barroso (1976); Heiden et al. (2009b).

Fig. 11

Subarbustos 1-2,5 $\mathrm{m}$ alt., apoiantes ou decumbentes. Caule e ramos 3-alados, alas 1-14 $\times 0,5-1,8 \mathrm{~cm}$, aplanadas a onduladas, resinosas, aparentemente glabras. Folhas 1-5 × 1-7 mm, escamiformes. Panículas $25-80 \mathrm{~cm}$ compr.; ramos espiciformes $10-35 \mathrm{~cm}$ compr., às vezes reduzidos a capítulos solitários ou glomérulos 2-8 capítulos. Capítulo masculino 3,8-5,4 mm alt.; invólucro 3,3-4,8 × 3,3-6,3 mm, 5-7-seriado, campanulado; brácteas involucrais externas ovadas, medianas ovadas a linear-elípticas, internas linear-elípticas, ápice acuminado, margens inteiras ou denticuladas, escariosas. Flores masculinas 12-25; corola 3-4,4 mm compr., tubo $2-2,5 \mathrm{~mm}$ compr., fauce $0,1-0,3$ mm compr., lacínias 1-1,7 mm compr.; estilete 3,5-4,3 mm compr.; papilho 2,5-3,7 mm compr., ápice levemente espessado. Capítulo feminino 4,8-7 mm alt.; invólucro 4-5,3 × 3-4,3 mm, 4-7-seriado, cilíndrico; brácteas involucrais externas e medianas ovadas, internas linearelípticas, ápice acuminado, denticulado, margens inteiras, escariosas. Flores femininas 25-56; corola 3-4,2 mm compr., ápice liguliforme, lígula com 1-2 dentículos; estilete 3,2-5 mm compr. Cipselas 0,6-1 mm compr., 12-20-costadas, glabras; papilho 3,5-5 $\mathrm{mm}$ compr.
Material selecionado: Angra dos Reis, 10.VII.1973, D. Sucre 10042 (CEPEC, R, RB). Barra do Piraí, 27.IV.1984, I.M. Silva 228 (RBR). Cachoeiras de Macacu, 30.V.1978, M.C. Vianna 1305 (GUA). Casimiro de Abreu, 14.I.2003, A.G. Christo 66 (RB). Engenheiro Paulo de Frontin, 20.VI.1993, M.C. Vianna 2299 (GUA). Itatiaia, 16.VI.1940, F. Stickney 1 (R). Miguel Pereira, 18.IV.2007, G. Heiden 727 (RB). Nova Friburgo, 31.V.1978, J.P.P. Carauta 2892 (GUA). Parati, 20.X.1993, R.C.C. Reis 68 (RB). Porciúncula, 9.I.1984, J.P.P. Carauta 4536 (GUA). Petrópolis, VI.1937, A.L. Gomes 72 (R). Quissamã, 5.XII.2007, O. Boscolo 113 (R). Resende, 26.VII.1966, G. Eiten 7447 (RB). Rio Bonito, 17.V.1991, M.F.A. Sá (R 183598). Rio de Janeiro, VI.2000, R.L. Esteves 462 (RB). Sapucaia, 31.V.1997, Y. Britto 152 (RB). Santa Maria Madalena, 14.V.2007, G. Heiden 734 (HECT, K, PEL, R, RB, RBR, SP), G. Heiden 735 (JE, K, R, R, RB, SP). Saquarema, 27.XII.1994, A.S. Fonseca 213 (RB). Silva Jardim, 14.VI.1994, S.V.A. Pessoa 714 (RB). Teresópolis, 27.VI.2007, G. Heiden 779, 780 (RB. Vassouras, 25.VI.1970, F. Segadas-Vianna 285 (R).

Material adicional selecionado: PARANÁ: Curitiba, X.1964, L.T. Dombrowski 469 (RB). São Mateus do Sul, 16.X.2005, G. Heiden 526 (RB).

Baccharis myriocephala apresenta ampla distribuição no leste da América do Sul, ocorrendo no Paraguai, Brasil e Argentina. No Brasil, ocorre nas Regiões Nordeste (BA, CE), Sudeste (ES, MG, RJ, SP) e Sul (PR, SC e RS), nos Biomas Caatinga, Cerrado, Mata Atlântica e Pampa. No estado do Rio de Janeiro (Fig. 12) é encontrada desde o nível do mar até $2000 \mathrm{~m}$, vegetando em áreas sob influência da Floresta Ombrófila Densa margeando formações de restinga, em florestas baixo-montanas, montanas e altimontanas e em afloramentos rochosos nos refúgios ecológicos montanos (inselbergues), tanto em áreas primárias, como em áreas secundárias em regeneração, ao lado de trilhas e clareiras, ou em áreas antropizadas, como margens de rodovias e terrenos baldios. Ocasionalmente é cultivada em quintais, pois é considerada com propriedades medicinais. Pode ser encontrada fértil ao longo de todo o ano, com pico de floração entre junho e setembro. Carqueja (Vianna 2299; Weinberg 588, 589; Zysko 255).

Baccharis myriocephala é comumente identificada como B. trimera $(=B$. crispa) no estado do Rio de Janeiro. Müller (2006) adotou uma circunscrição ampla para $B$. genistelloides subsp. crispa, incluindo estes dois binômios na sinonímia. Entretanto, B. trimera é aceita como um sinônimo de $B$. crispa, enquanto que 


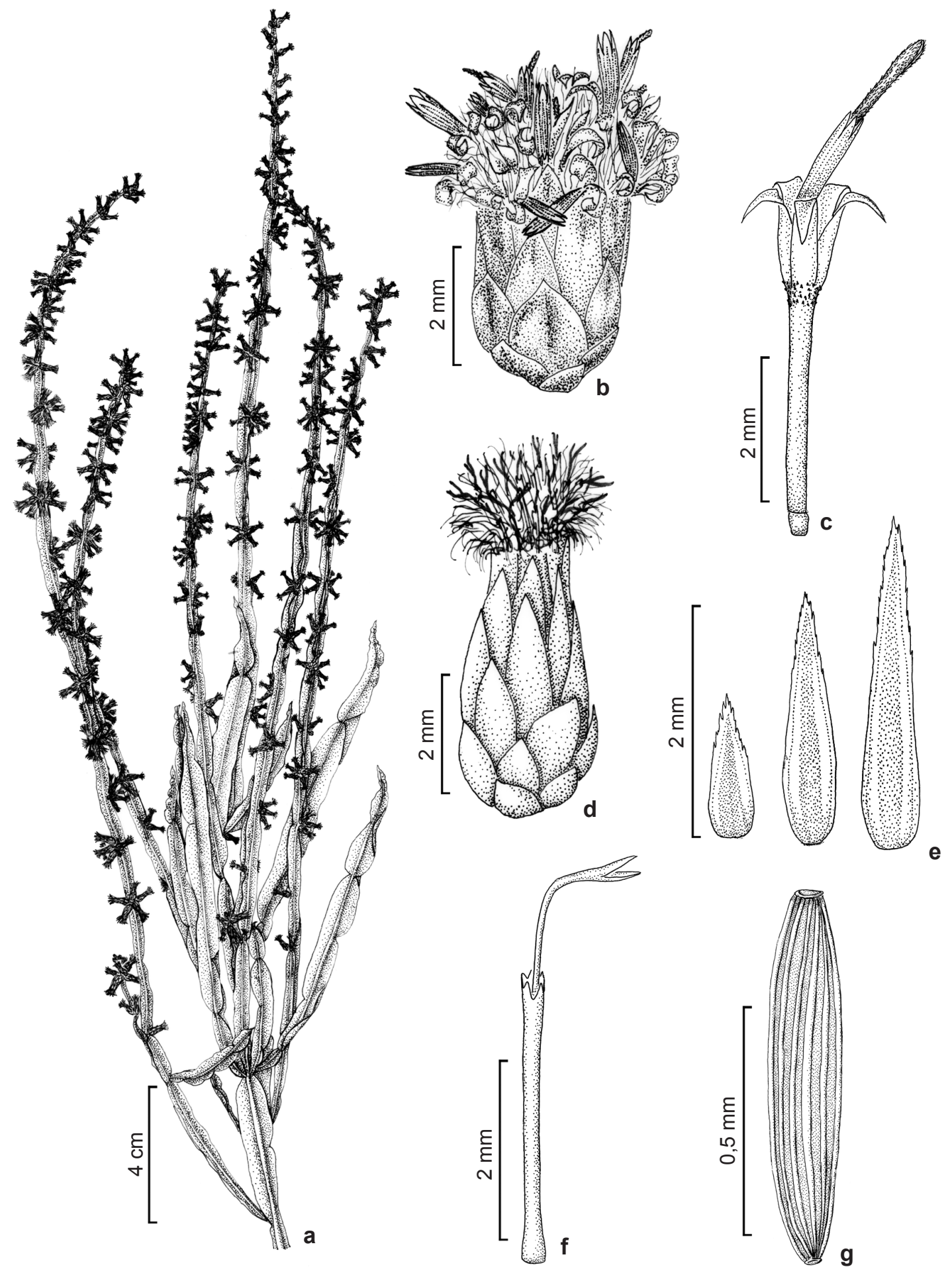

Figura 11 - Baccharis myriocephala DC.: a. ramo florífero, planta feminina; b. capítulo masculino; c. flor masculina (papilho removido); d. capítulo feminino; e. brácteas involucrais do capítulo feminino; f. corola e estilete da flor feminina; g. cipsela (a, d: Heiden 526; b: Dombrowski 469; c: Heiden 735; e-g: Heiden 779).

Figure 11 - Baccharis myriocephala DC.: a. flowering shoot, female plant; b. male capitulum; c. male floret (pappus removed); D. female capitulum; E. phyllaries of female capitulum; F. corolla and style of female floret; g. cypsela (a, d: Heiden 526; b: Dombrowski 469; c: Heiden 735; e-g: Heiden 779). 
B. myriocephala é, por hora, considerada um táxon autonômo e próximo de $B$. crispa, porém distinto deste, conforme discutido previamente (Heiden et al. 2009b). Todavia, a delimitação dessas espécies merece estudos mais aprofundados ao longo de toda a área de distribuição desses táxons na América do Sul de forma a esclarecer a circunscrição de ambos.

10. Baccharis organensis Baker in Martius, Fl. bras. 6(3): 74. 1882. Ilustrações: Malagarriga (1976); Heiden et al. (2009b).

Fig. 13

Subarbustos ou arbustos $0,5-1,8 \mathrm{~m}$ alt., eretos ou apoiantes. Caule e ramos ápteros, estriados. Folhas pecíolo 3-6 mm compr.; lâmina 1,1-3,2 $\times 0,5-1,7 \mathrm{~cm}$, coriácea, oblonga a ovada, ápice arredondado a agudo, margens inteiras, base arredondada a cuneada; nervação actinódroma; face abaxial opaca, face adaxial resinosa, ambas aparentemente glabras. Panículas 1,5-6 × 1-6 $\mathrm{cm}$, piramidais, terminais; ramos espiciformes, 0,5-3 cm compr. Capítulo masculino 2,5-4 mm alt.; invólucro 2,6-3,1 × 2,1-4,1 mm, 3-4-seriado, campanulado; brácteas involucrais externas e medianas ovadas, internas elípticas, ápice denteado a curtamente fimbriado, margens denteadas a curtamente laciniadas, escariosas. Flores masculinas 16-28; corola 1,8-2 mm compr., tubo $1-1,2 \mathrm{~mm}$ compr., fauce $0,2-0,5$ $\mathrm{mm}$ compr., lacínias $0,3-0,5 \mathrm{~mm}$ compr.; estilete 1,8-2,2 mm compr.; papilho $2-2,5 \mathrm{~mm}$ compr., ápice não espessado. Capítulo feminino $3,5-5 \mathrm{~mm}$ alt.; invólucro 3-4,3 × 2,7-53 mm, 3-4-seriado,

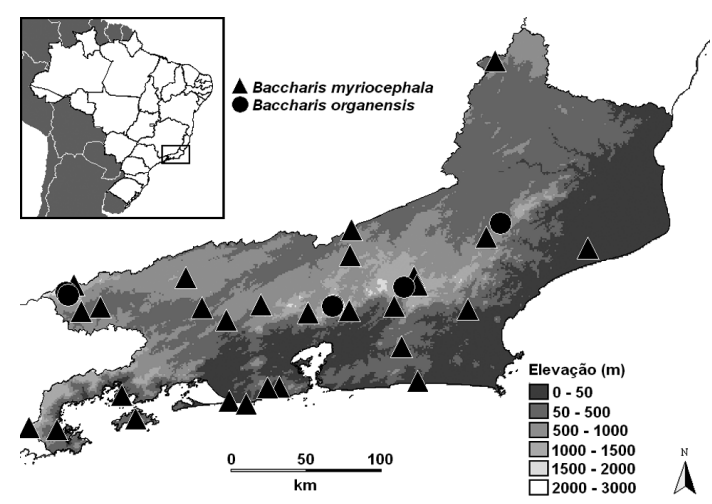

Figura 12 - Distribuição geográfica de Baccharis myriocephala DC. ( $(\boldsymbol{\Delta})$ e B. organensis Baker $(\bullet)$ no estado do Rio de Janeiro.

Figure 12-Geographic distribution of Baccharis myriocephala DC. $(\boldsymbol{\Delta})$ and B. organensis Baker $(\bullet)$ in Rio de Janeiro state, Brazil. cilíndrico a campanulado; brácteas involucrais externas ovadas, medianas oblongas, internas ovadas a oblongas, ápice denteado a curtamente laciniado, margens denteadas, escariosas. Flores femininas 30-42; corola 2-2,4 mm compr., ápice 5-denticulado, dentículos desiguais; estilete 2,5-3,2 mm compr. Cipselas 1,2-1,5 mm compr., 5-6-costadas, glandulosas nas costelas; papilho 2-2,5 mm compr.

Material selecionado: Nova Friburgo, III.2007, G. Heiden 713 (K, PEL, RB, SP). Itatiaia, XII.1964, M.C. Vianna 195 (GUA, RB). Petrópolis, XI.1929, A.C. Brade 9894 (R). Resende, IX.2007, G. Heiden 829 (JE, RB). Santa Maria Madalena, X.1988, G. Martinelli 13108 (R, RB). Teresópolis, 26.IX.2007, G. Heiden 882 (RB); 27.IX.2007, G. Heiden 899 (JE, K, RB, SP).

Material adicional selecionado: RIO GRANDE DO SUL: Cambará do Sul, XII.1950, B. Rambo (PACA49388); XI.1953, B. Rambo (PACA 54487).

Baccharis organensis é restrita ao Brasil, ocorrendo nas Regiões Sudeste (MG, RJ, SP) e Sul (PR, SC, RS), no Bioma Mata Atlântica. No estado do Rio de Janeiro (Fig. 12) ocorre em altitudes entre 2000 e 2400 m, no maciço do Itatiaia (Serra da Mantiqueira) e na Serra dos Órgãos, Pico da Caledônia e Pico do Desengano (Serra do Mar), formando populações esparsas, com indivíduos apoiantes em ambientes sombreados nas bordas de florestas altimontanas ou densas com espécimes arbustivos eretos em bordas de matas nebulares e campos de altitude, onde ocorre em encostas. Floresce de outubro a dezembro; a dispersão das cipselas pode perdurar até março. Alecrim (Heiden 882).

Baccharis organensis pertence a sect. Caulopterae, embora não pareça evidente devido aos ramos estriados e limbo foliar nitidamente expandido. Entretanto, compartilha com as demais espécies da seção capítulos femininos com clinanto glanduloso e desprovido de páleas, corola das flores femininas destituída de coroa subapical de tricomas e papilho não acrescente com cerdas espessadas na base e fundidas em anel. Pode ser confundida com B. trinervis (sect. Trinervatae), da qual se distingue pelo capítulo feminino desprovido de páleas e com clinanto glanduloso.

11. Baccharis regnellii Sch.Bip. ex Baker in Martius, Fl. bras. 6(3): 74. 1882. Ilustração: Malagarriga (1976).

Fig. 14

Arbustos 1-3 m alt. eretos. Caule e ramos ápteros, estriados. Folhas com pecíolo $2-5,2 \mathrm{~mm}$ compr.; lâmina 1,5-5,7 ×0,3-3,6 cm, face abaxial 

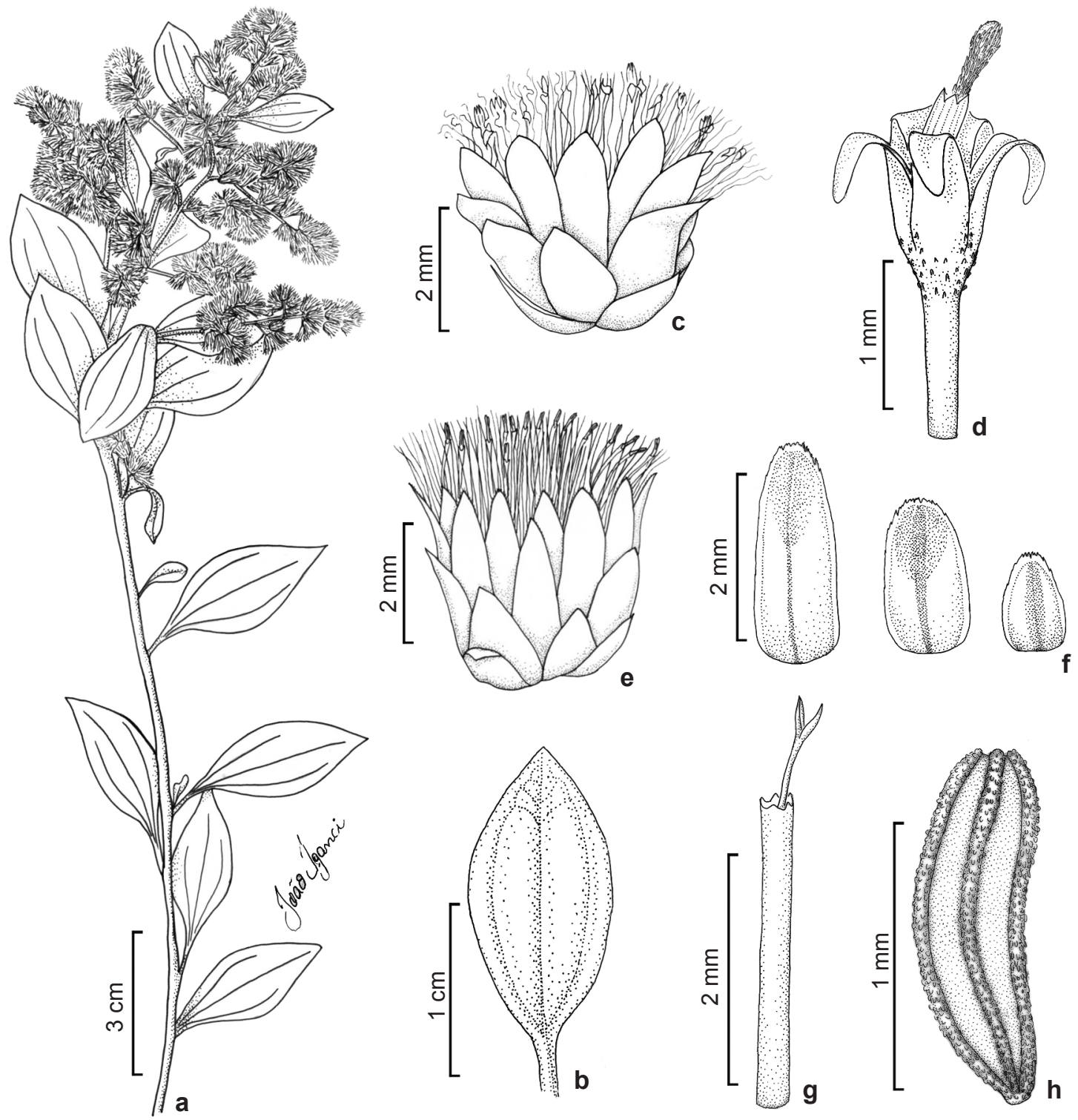

Figura 13 - Baccharis organensis Baker: a. ramo florífero, planta feminina; b. folha; c. capítulo masculino; d. flor masculina (ovário vestigial e papilho removidos); e. capítulo feminino; f. brácteas involucrais do capítulo feminino; g. corola e estilete da flor feminina; h. cipsela (a, b, e: Rambo s.n., PACA 49388; c: Rambo (PACA 54487); d: Heiden 899; f-h: Heiden 882). Figure 13 - Baccharis organensis Baker: a. flowering shoot, female plant; b. leaf; c. male capitulum; d. male floret (pappus and vestigial ovary removed); e. female capitulum; f. phyllaries of female capitulum; g. corolla and style of female floret; h. cypsela (a, b, e: Rambo s.n., PACA 49388; c: Rambo (PACA 54487); d: Heiden 899; f-h: Heiden 882).

opaca, face adaxial resinosa, cartácea, elíptica a lanceolada, ápice agudo a acuminado, margens crenuladas, revolutas, base obtusa a atenuada; peninérvea ou nervação actinódroma, $1-5 \mathrm{~mm}$ suprabasal; ambas as faces aparentemente glabras. Panículas $4-16 \times 2-10 \mathrm{~cm}$, terminais, piramidais; ramos espiciformes $0,5-9 \mathrm{~cm}$ compr.
Capítulo masculino 3-5 $\mathrm{mm}$ alt.; invólucro 2-3,6 × 2,4-4,5 mm, 3-4-seriado, campanulado; brácteas involucrais externas e medianas ovadas, internas elípticas, ápice denteado, margens inteiras, escariosas. Flores masculinas $14-38$; corola 2,8-3,4 mm compr., tubo 1,8-2,2 $\mathrm{mm}$ compr., fauce $0-0,1 \mathrm{~mm}$ compr., lacínias 
1-1,2 mm compr.; estilete 2,8-3,4 mm compr.; papilho 2,7-3 mm compr., ápice não espessado. Capítulo feminino 3,1-5,1 mm alt., invólucro 2,8-4,4 × 2,1-5,9 mm, 4-5-seriado, cilíndrico a campanulado; brácteas involucrais externas e medianas ovadas, internas linear-elípticas, ápice fimbriado, margens inteiras ou denteadas, estreitamente escariosas; flores 20-42; corola 2,2-2,9 mm compr., ápice denticulado; estilete 2,4-3,1 mm compr. Cipselas 0,7-1 mm compr., 5-8-costadas, papilosas nas costelas; papilho 2,9-3,2 mm compr.

Material examinado: Nova Friburgo, 25.VIII.1935, H. Monteiro Filho 1320 (RB, RBR); 9.X.1993, C.M. Vieira 431 (RB).

Material adicional selecionado: MINAS GERAIS: Poços de Caldas, 9.IX.1964, M. Emmerich 2020 (RB).

Baccharis regnellii apresenta distribuição restrita ao Brasil, na região Sudeste (MG, RJ, SP), com ocorrência no Bioma Mata Atlântica. No estado do Rio de Janeiro (Fig. 9) é encontrada em altitudes superiores a $1500 \mathrm{~m}$, com registros apenas no município de Nova Friburgo, às margens da rodovia Friburgo-Teresópolis e na localidade de Macaé de Cima. Trata-se de um arbusto heliófilo que medra em orlas de florestas e áreas com vegetação secundária. Floresce e frutifica entre agosto e outubro.

Baccharis regnellii é estreitamente relacionada com $B$. burchellii, porém pode ser diferenciada da mesma como discutido previamente no presente estudo.

III. Baccharis subgen. Molina sect. Molinae (Pers.) Cuatrec., Revista Acad. Colomb. Ci. Exact. 13(49): 15. 1967.

Baccharis sect. Molinae corresponde ao Grupo Baccharis latifolia sensu Müller (2006), compreendendo ca. 30 espécies que ocorrem do sul dos Estados Unidos até a Patagônia, estando ausente, porém, em muitas partes do nordeste da América do Sul e nas Índias Ocidentais. No Brasil ocorrem seis espécies da seção, das quais duas B. conyzoides (Less.) DC. e B. salicifolia (Ruiz $\&$ Pav.) Pers. - não possuem registro no estado do Rio de Janeiro. As demais são encontradas no estado principalmente em bordas de florestas e áreas secundárias em regeneração, sendo raras em inselbergues e campos de altitude, embora B. stylosa seja restrita a esses habitats. Barroso (1976) considerou os táxons desta seção nos
Grupos Serrulata (B. serrulata e B. stylosa), Oxyodonta ( $B$. oxyodonta) e Punctulata $(B$. punctulata e $B$. conyzoides), enquanto que $B$. salicifolia não havia sido citada para o Brasil pela autora.

As espécies do Rio de Janeiro são caracterizadas pelo caule cilíndrico, liso; folhas desenvolvidas, com ambas as faces pilosas ou glabrescentes, e margens serreadas; panículas piramidais ou corimbiformes, ou racemos, oblongos; capítulos com clinanto destituído de páleas; corola das flores femininas denticulada ou truncada e com uma coroa subapical de tricomas bisseriados; e cipselas glabras, papilosas ou pubérulas, com papilho unisseriado, acrescente ou não.

12. Baccharis oxyodonta DC., Prodr. 5: 404. 1836. Pingraea oxyodonta (DC.) F.H.Hellw., Candollea 48: 218. 1993. Ilustrações: Baker (1882); Barroso (1976).

Fig. 15

Subarbustos escandentes, $1-2,5 \mathrm{~m}$ alt. Folhas com pecíolo $0,5-1,8 \mathrm{~cm}$ compr.; lâmina $3,4-12,4 \times 0,7-3,7 \mathrm{~cm}$, membranácea, linearelíptica, lanceolada ou ovada, ápice agudo ou acuminado, base obtusa, arredondada ou cuneada; 3 nervuras acródromas 0,2-1,2 mm suprabasais ou nervação actinódroma, às vezes com um par adicional marginal; ambas as faces com pouca resina ou não resinosas, pubérulas, tricomas unisseriados esparsos. Racemos ou panículas 1,5-11,5 × 1,4-3,8 cm, oblongos, pêndulos, axilares, às vezes também terminais; pedúnculos $1-5 \mathrm{~mm}$ compr., brácteas foliáceas 4-12 × 1-3,5 cm. Capítulo masculino 3,1-5,8 $\mathrm{mm}$ alt.; invólucro $2,9-4,5 \times 2,7-7,2 \mathrm{~mm}$, 3 -seriado; brácteas involucrais externas e medianas ovadas a lanceoladas, internas lineares, ápice denteado a fimbriado, margens denteadas. Flores masculinas 10-22; corola 3,3-5 mm compr., tubo $2,3-2,8 \mathrm{~mm}$ compr., fauce $0-0,2$ mm compr., lacínias 1-1,6 mm compr.; anteras exsertas; estilete 3,4-5 mm compr.; papilho 2,3-3,4 mm compr., ápice levemente espessado. Capítulo feminino 4-9,8 $\mathrm{mm}$ alt.; invólucro 3,3$5 \times 3,2-10 \mathrm{~mm}, 3-4$-seriado; brácteas involucrais externas ovadas, medianas e internas oblongas a elípticas, ápice fimbriado, margens denteadas, estreitamente escariosa. Flores femininas 92180; corola 1,1-1,7 mm compr., ápice denteado, coroa subapical de tricomas ausente; estilete 

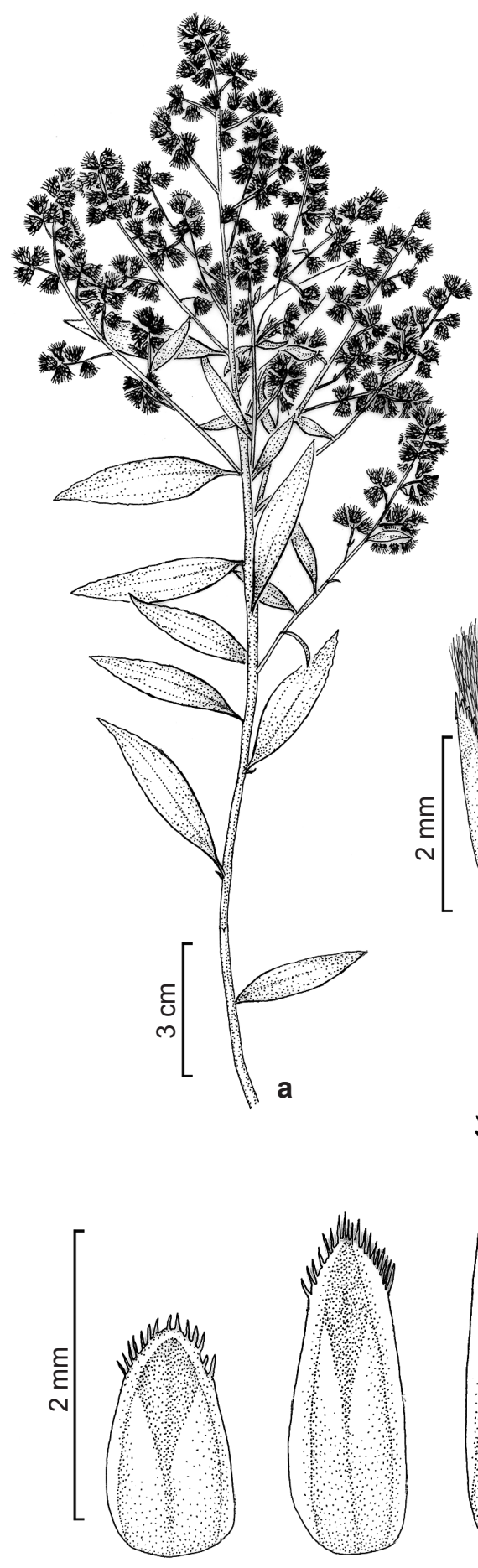
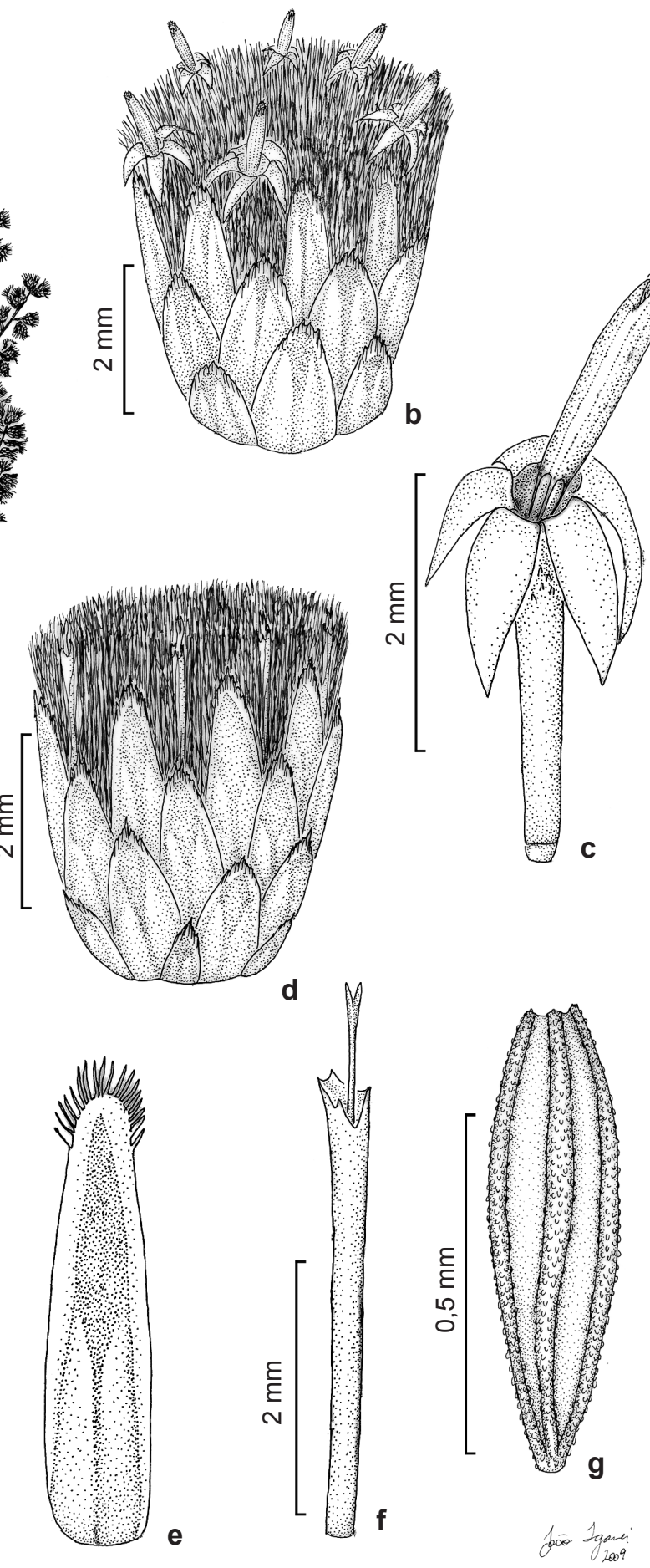

Figura 14 - Baccharis regnellii Sch.Bip. ex Baker: a. ramo florífero, planta feminina; b. capítulo masculino; c. flor masculina (papilho removido); d. capítulo feminino; e. brácteas involucrais do capítulo feminino; f. corola e estilete da flor feminina; g. cipsela (a, d-g: Vieira 431; c, d: Emmerich 2020).

Figure 14 - Baccharis regnellii Sch.Bip. ex Baker: a. flowering shoot, female plant; b. male capitulum; c. male floret (pappus removed); d. female capitulum; e. phyllaries of female capitulum; f. corolla and style of female floret; g. cypsela (a, d-g: Vieira 431; c, d: Emmerich 2020). 


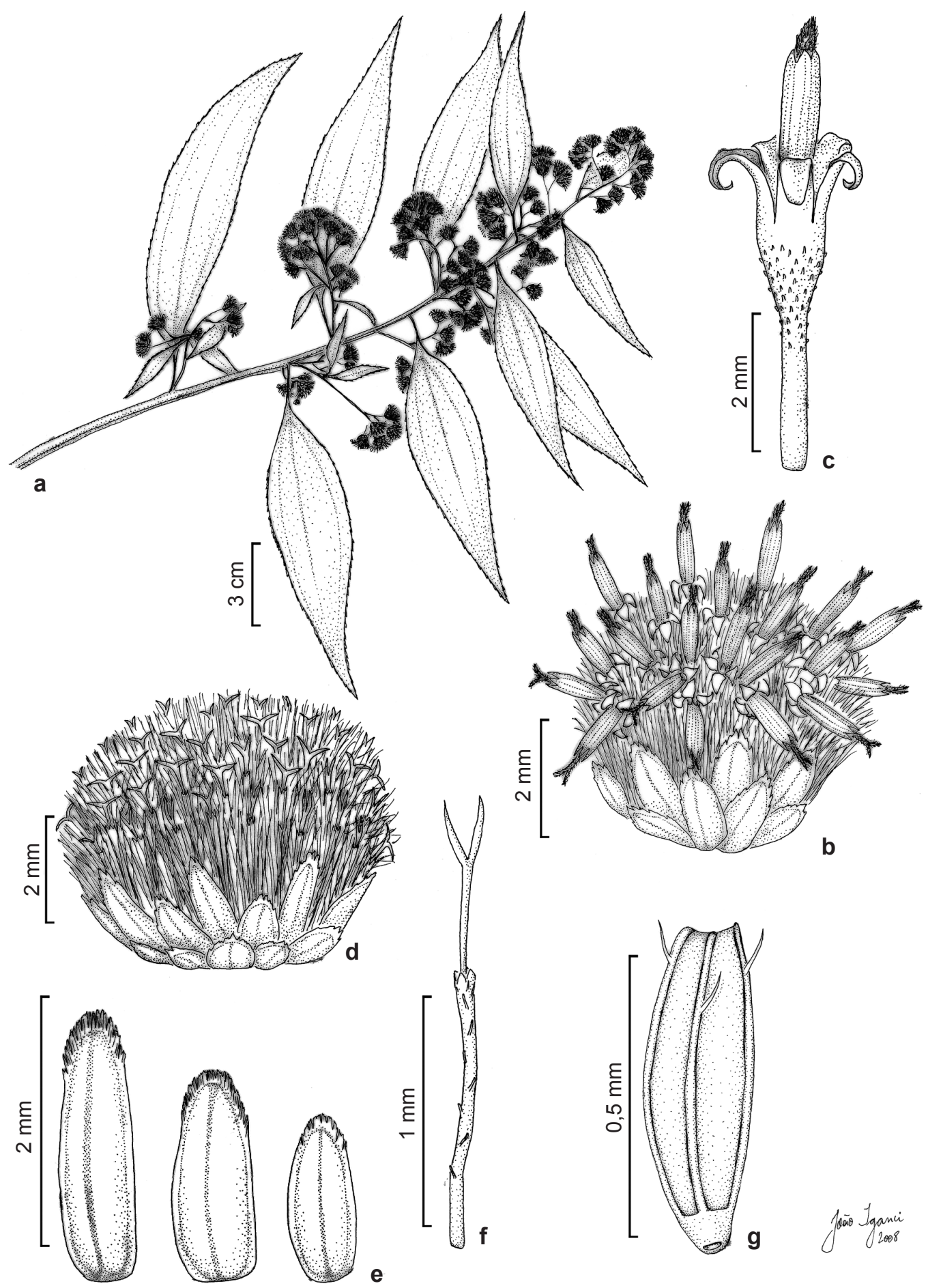

Figura 15 - Baccharis oxyodonta DC.: a. ramo florífero, planta masculina; b. capítulo masculino; c. flor masculina (ovário vestigial e papilho removidos); d. capítulo feminino; e. brácteas involucrais do capítulo feminino; f. corola e estilete da flor feminina; g. cipsela. (a: Brade 16714; b, c: Esteves 2152; d-g: Heiden 859).

Figure 15 - Baccharis oxyodonta DC.: a. flowering shoots, male plant; B. male capitulum; C. male floret (pappus and vestigial ovary removed); d. female capitulum; E. phyllaries of female capitulum; F. corolla and style of female floret; g. cypsela. (a: Brade 16714; b, c: Esteves 2152; d-g: Heiden 859). 
1,1-2 mm compr. Cipselas 0,4-0,6 mm compr., 4-6-costadas, pubérulas; papilho 1,5-2,4 mm compr., acrescente.

Material selecionado: Barra do Piraí, 12.IV.1992, M.T.A.V. Braga 4 (GUA). Itatiaia, 24.VI.2005, R.L. Esteves 2152 (HB, HRJ, RB). Nova Friburgo, 12.VIII.1987, M. Nadruz 317 (RB). Petrópolis, VII.1874, A.F.M. Glaziou 7699 (R). Teresópolis, IX.1940, A.C. Brade 16714 (RB); 24.IX.2007, G. Heiden 859 (RB).

Baccharis oxyodonta apresenta distribuição ampla no Paraguai, Brasil, Uruguai e Argentina. No Brasil ocorre nas Regiões Sudeste (ES, MG, RJ, SP) e Sul (PR, SC e RS), nos Biomas Cerrado, Mata Atlântica e Pampa. No estado do Rio de Janeiro (Fig. 16) é uma espécie característica da faixa altitudinal entre 800 e $1800 \mathrm{~m}$, em bordas de formações florestais montanas e altimontanas, ocorrendo na Serra dos Órgãos e na Serra do Itatiaia. Trata-se de um subarbusto semi-heliófilo a ciófilo, que pode ser encontrado em bordas de mata e ao longo de cursos d'água ou em locais antropizados, como trilhas e áreas com vegetação secundária. Encontra-se fértil de junho a outubro. Alecrim-da-mata (Heiden 859).

Baccharis oxyodonta pode ser facilmente reconhecida dentro da seção pelos racemos ou panículas, predominantemente axilares, cujas brácteas foliáceas excedem as capitulescências em comprimento.

13. Baccharis punctulata DC., Prodr. 5: 405. 1836. Baccharis oxyodonta var. punctulata (DC.) Baker in Martius, Fl. bras. 6(3): 77. 1882. Pingraea punctulata (DC.) F.H.Hellw., Candollea 48: 218. 1993. Ilustrações: Teodoro (1954); Malagarriga (1976); Cabrera (1974, 1978); Müller (2006).

Fig. 17

Arbustos ou subarbustos, $0,6-2,5 \mathrm{~m}$ alt. Folhas com pecíolo $0,2-1,1 \mathrm{~cm}$ compr.; lâmina $2,2-9,8 \times 0,4-24,5 \mathrm{~cm}$, coriácea, elíptica a ovada, ápice agudo, base cuneada; 3 nervuras acródromas $0,5-1 \mathrm{~cm}$ suprabasais, ambas as faces com pouca resina ou não resinosas, aparentemente glabras. Panículas 8-30 × 7-18 $\mathrm{cm}$, piramidais, às vezes cilíndricas, geralmente terminais, às vezes axilares, concentradas no ápice dos ramos; pedúnculos 1-8 $\mathrm{mm}$ compr.; brácteas reduzidas ou escamiformes $0,3-1,5 \times$ $0,1-0,7 \mathrm{~cm}$, mais curtas que a capitulescência. Capítulo masculino 4,5-7,3 mm alt.; invólucro

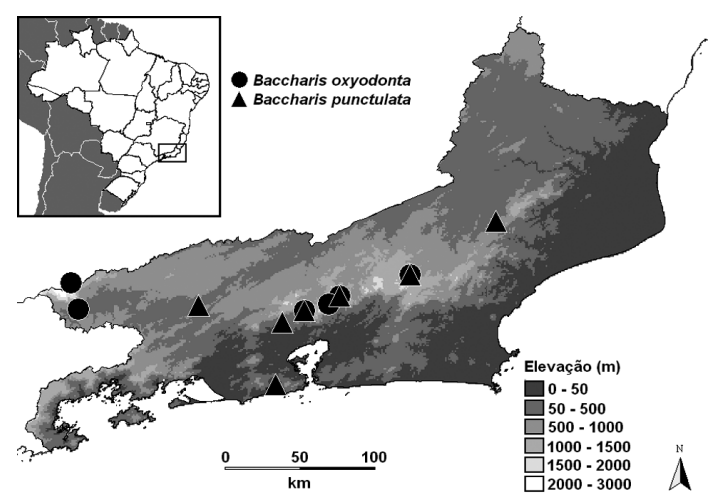

Figura 16 - Distribuição geográfica de Baccharis oxyodonta DC. ( $\bullet$ e B. punctulata DC. ( $(\boldsymbol{\Delta})$ no estado do Rio de Janeiro.

Figure 16-Geographic distribution of Baccharis oxyodonta DC. (O) and B. punctulata DC. ( $\mathbf{\Delta})$ in Rio de Janeiro state, Brazil.

3,7-5,2 × 3,8-8,1 mm, 3×4-seriado; brácteas involucrais externas e medianas ovadas, internas lanceoladas a lineares, ápice fimbriado, margens curtamente fimbriadas ou denteadas, escariosa. Flores masculinas $20 \times 45$; corola $4-5,5 \mathrm{~mm}$ compr., tubo $2-2,5 \mathrm{~mm}$ compr., fauce $0,2-0,5$ mm compr., lacínias 1,7-2,5 mm compr.; anteras exsertas; estilete 5-6,3 $\mathrm{mm}$ compr.; papilho 2,5-4,5 mm compr., ápice espessado. Capítulo feminino 3,7-9,6 mm alt.; invólucro 3,3-5,4 × 2,3-6,7 mm, 3-5-seriado; brácteas involucrais externas ovadas, medianas elípticas, internas linear-elípticas, ápice fimbriado, margens inteiras, escariosas. Flores femininas 70-150; corola 2,5-3,5 mm compr., ápice truncado, coroa subapical de tricomas presente; estilete $3,5-5 \mathrm{~mm}$ compr. Cipselas 1,5-2 mm compr., cilíndricas, levemente achatadas, 6-8-costadas, pubérulas; papilho 4-6 mm compr., não acrescente.

Material selecionado: Nova Friburgo, 18.II.1966, A.P. Duarte 9573 (HB, RB). Mendes, 9.III.1948, A.M. Comatta 82 (R). Nova Iguaçu, 9.II.1880, C. Capanema (RB 16017). Petrópolis, I.1944, O.C. Góes 54 (RB);. Rio de Janeiro, 12.XII.1998, R.L. Esteves 335 (R). Santa Maria Madalena, 25.VI.1987, H.C. Lima 3007 (R, RB). Teresópolis, VII.1935, J. Deslandes 2 (SP).

Material adicional selecionado: SÃO PAULO: Campinas, 27.V.2001. A.C. Siani (RB 457108).

Baccharis punctulata possui distribuição ampla na Bolívia, Paraguai, Brasil, Uruguai e Argentina. No Brasil, ocorre nas Regiões Sudeste (ES, MG, RJ, SP) e Sul (PR, SC e 


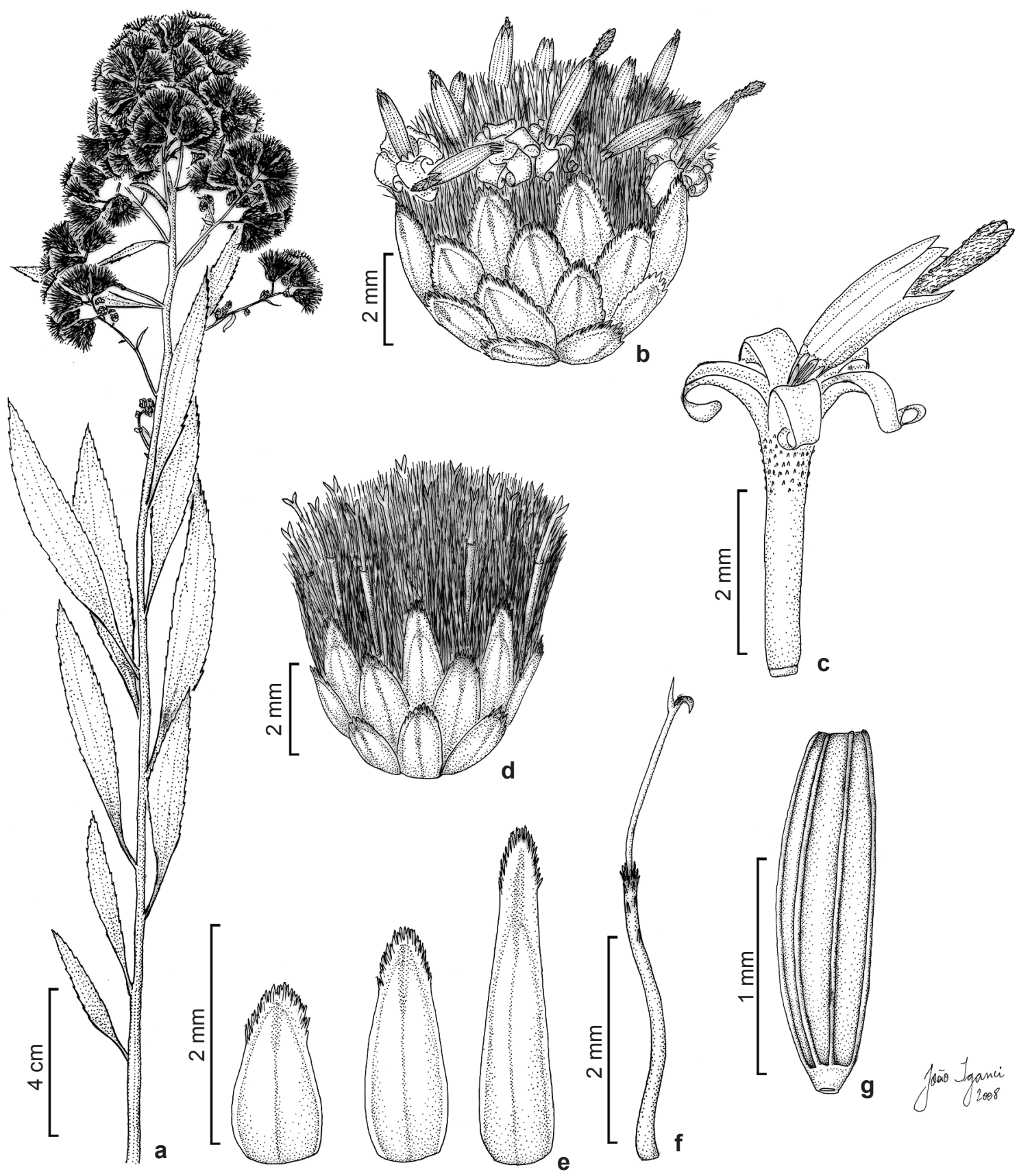

Figura 17 - Baccharis punctulata DC.: a. ramo florífero, planta feminina; b. capítulo masculino; c. flor masculina (papilho removido); d. capítulo feminino; e. brácteas involucrais do capítulo feminino; f. corola e estilete da flor feminina; g. Cipsela (a, d-g: Siani (RB 457108); b, c: Góes 54).

Figure 17 - Baccharis punctulata DC.: a. flowering shoot, female plant; b. male capitulum; c. male floret (pappus removed); d. female capitulum; e. phyllaries of female capitulum; f. corolla and style of female floret; g. cypsela (a, d-g: Siani (B 457108); b, c: Góes 54). 
RS), nos Biomas Cerrado, Mata Atlântica e Pampa. No estado do Rio de Janeiro (Fig. 16) é encontrada desde o nível do mar até $1800 \mathrm{~m}$, vegetando em bordas de formações florestais baixo-montanas, montanas, altimontanas e, às vezes, em afloramentos rochosos nos refúgios ecológicos montanos (inselbergues), tanto em áreas primárias, quanto secundárias em regeneração, ao longo de trilhas e clareiras. Pode ser encontrada fértil de janeiro a junho. Arrebentão (Dedecca 380); erva-de-sant'ana (Deslandes 2).

Baccharis punctulata é confundida $\operatorname{com} B$. serrulata, da qual pode ser diferenciada pelas folhas coriáceas, não viscosas, capitulescências geralmente piramidais, às vezes cilíndricas $(6-15 \times 4-9,5 \mathrm{~cm})$ e capítulos femininos com 70-150 flores.

14. Baccharis serrulata (Lam.) Pers., Syn. Pl. 2(2): 423. 1807. Conyza serrulata Lam., Encycl. 2: 85. 1786. Ilustrações: Barroso (1976); Malagarriga (1976); Borges \& Forzza (2008).

Fig. 18

Subarbustos $0,4-2 \mathrm{~m}$ alt., eretos, eretoprostrados ou apoiantes. Caule e ramos pilosos, glabrescentes, tricomas unisseriados e bisseriados. Folhas com pecíolo 0,5-2,7 cm compr.; lâmina 2,6-10,1 × 0,4-5,5 cm, membranácea, ovada a linear-elíptica, ápice acuminado, atenuado ou agudo, base obtusa; 3 nervuras acródromas 1-8,5 $\mathrm{mm}$ suprabasais, ambas as faces com pouca resina, viscosas, foscas, pilosas ou glabrescentes, tricomas unisseriados, multicelulares e em pedestal. Panículas 6-15 × 4-9,5 cm, geralmente corimbiformes, às vezes piramidais, terminais, densas a laxas; pedúnculos $0,5-7 \mathrm{~mm}$ compr. Capítulo masculino 2,1-3,5 mm alt.; invólucro 1,8-2,6 × 1,7-3,6 mm, 3-6-seriado; brácteas involucrais externas ovadas, medianas e internas elípticas, ápice fimbriado, margens fimbriadas, escariosas. Flores masculinas 16-24; corola $1,5-1,9 \mathrm{~mm}$ compr., tubo $0,5-0,7 \mathrm{~mm}$ compr., fauce $0,1-0,2 \mathrm{~mm}$ compr., lacínias $0,8-1,2 \mathrm{~mm}$ compr.; anteras levemente exsertas; estilete 1,5-2 $\mathrm{mm}$ compr.; papilho 1,5-1,7 mm compr., ápice espessado. Capítulo feminino 2,4-4,9 mm alt.; invólucro 2,2-3,2 × 2-4,4 $\mathrm{mm}, 3-7$-seriado; brácteas involucrais externas ovadas, medianas e internas elípticas, ápice e margens fimbriadas, estreitamente escariosa. Flores femininas 38-50; corola $0,9-1,3 \mathrm{~mm}$ compr., ápice truncado, coroa subapical de tricomas presente; estilete 2-2,3 mm compr. Cipselas 1,1-2 mm compr., cilíndricas, 4-6-costadas, pubérulas; papilho 1,8-2,2 $\mathrm{mm}$ compr., não acrescente.

Material selecionado: Armação dos Búzios, 9.IX.1995, R. Scheel-Ybert 11 (GUA). Bom Jardim, 14.XII.1988, J.P.P. Carauta 5710, 5715 (GUA). Bom Jesus de Itabapoana, IX.1909, A.J. Sampaio 935 (R). Campos dos Goytacazes, 17.V.2007, G. Heiden 766, 767 (RB). Casimiro de Abreu, 21.IV.1983, R.L. Esteves 137 (R). Duas Barras, 13.XII.1988, S.R. Sodré 23 (GUA). Engenheiro Paulo de Frontin, 22.X.2000, R.E. Santos 52 (RFFP). Itaipuaçu, 18.XI.1988, R.L. Esteves 331 (R). Macaé, 23.IV.1994, J.M.A. Braga 1154 (RB). Magé, 28.XII.1988, A. Souza 2532 (R). Mangaratiba, 5.III.2006, T.A. Amorim 10 (RBR). Maricá, 21.X.1994, Ramos 276 (RB). Niterói, 9.II.1944, J.E. Vidal I.52 (R). Nova Friburgo, 21.III.2007, G. Heiden 706 (HECT, PEL, R, RB). Petrópolis, III.1942, P.P.H. Laclette (R 35052). Resende, 13.IX.2007, G. Heiden 855, 856 (RB). Rio das Ostras, 31.X.1998, R.N. Damasceno 1175 (RB). Rio de Janeiro, XI.1966, D. Sucre 1211 (HB, RB). Santa Maria Madalena, V.2007, G. Heiden 751 (HECT, JE, K, PEL, R, RB, RBR, SP). Saquarema, V.2005, R.L. Esteves 2148 (HRJ, RB). São Sebastião do Alto, VI.1994, J.P.P. Carauta 6924 (GUA). Silva Jardim, VII.1989, R.L. Esteves 467, 468 (R). Teresópolis, II.1968, D. Sucre 2307 (RB). Vassouras, III.1940, H. Monteiro Filho 2330 (RBR).

Baccharis serrulata apresenta ampla distribuição no Brasil, onde ocorre nas Regiões Nordeste (BA e PE), Sudeste (ES, MG, RJ, SP) e Sul (PR, SC e RS), nos Biomas Caatinga, Cerrado e Mata Atlântica. No estado do Rio de Janeiro (Fig. 19) ocorre desde o nível do mar até 1800 $\mathrm{m}$ de altitude, vegetando em áreas de Floresta Ombrófila Densa, em bordas de formações de restingas, florestas baixo-montanas, montanas e altimontanas e em afloramentos rochosos nos refúgios ecológicos montanos (inselbergues), tanto em áreas primárias, quanto secundárias em regeneração, ao longo de trilhas e clareiras. Fértil de abril a novembro, com pico de floração entre maio e junho. Arnica (Santos 373); ervade-coelho, vara-de-visgo (Heiden 855, 856); joão-russo (Maiolino, (RBR 8792)).

Baccharis serrulata é uma espécie reconhecível pelo hábito subarbustivo, folhas membranáceas, pilosas ou glabrescentes, superfície viscosa, face adaxial fosca e margens 


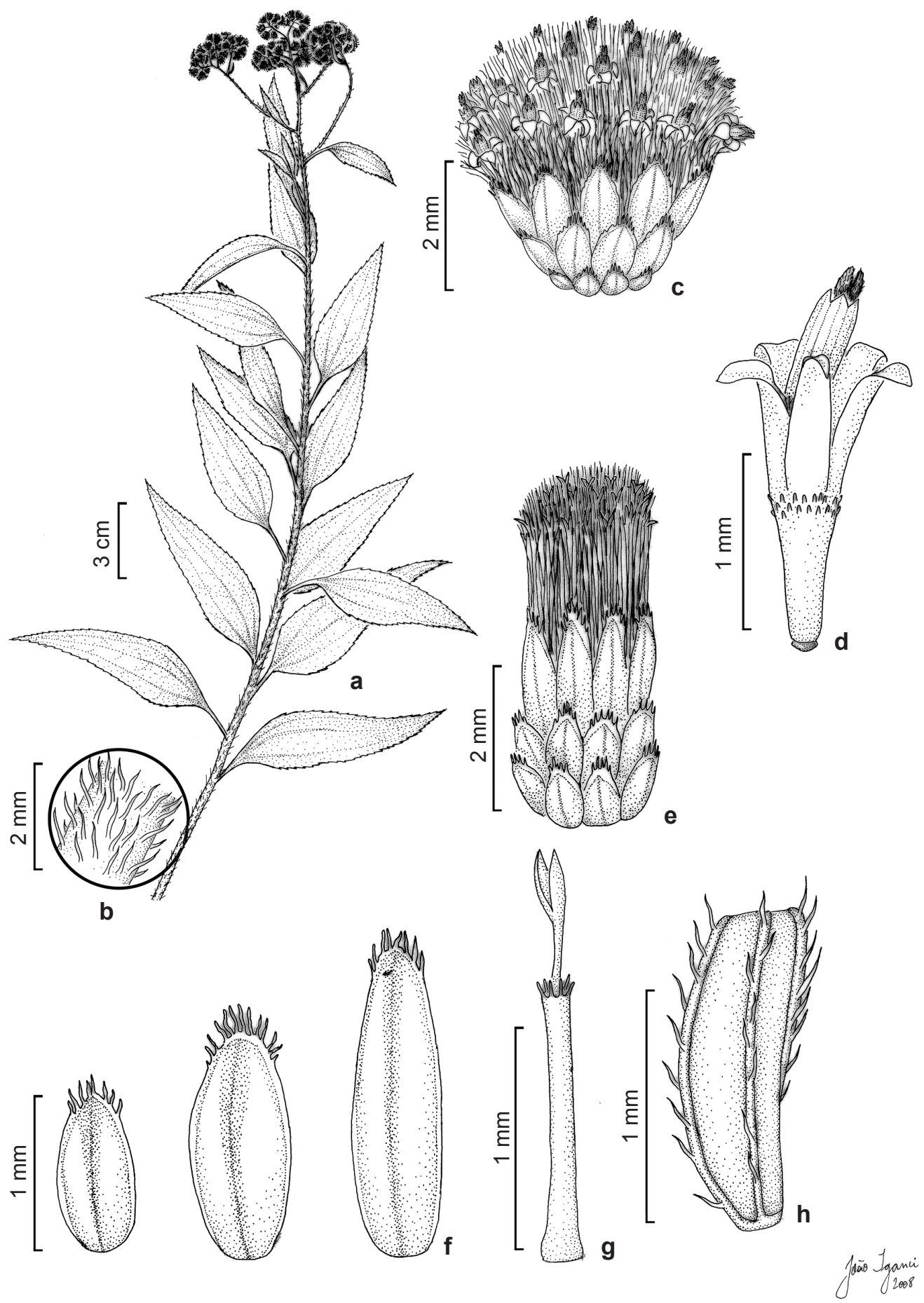

Figura 18 - Baccharis serrulata (Lam.) Pers.: a. ramo florífero, planta masculina; b. indumento do caule; c. capítulo masculino; d. flor masculina (papilho removido); e. capítulo feminino; f. brácteas involucrais do capítulo feminino; g. corola e estilete da flor feminina; h. cipsela (a, b, e-h: Heiden \& Baumgratz 855; c, d: Heiden \& Baumgratz 856). Figure 18 - Baccharis serrulata (Lam.) Pers.: a. flowering shoot, male plant; b. stem indumentum; c. male capitulum; d. male floret (pappus removed); e. female capitulum; f. phyllaries of female floret; g. corolla and style of female floret; h. cypsela (a, b, e-h: Heiden \& Baumgratz 855; c, d: Heiden \& Baumgratz 856). 


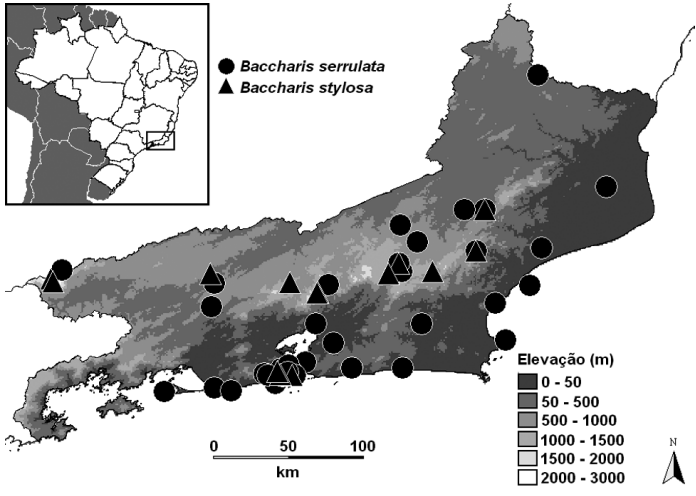

Figura 19 - Distribuição geográfica de Baccharis serrulata (Lam.) Pers. (•) e B. stylosa Gardner ( $\mathbf{(})$ no estado do Rio de Janeiro.

Figure 19-Geographic distribution of Baccharis serrulata (Lam.) Pers. ( $)$ and B. stylosa Gardner ( $\mathbf{\Delta})$ in Rio de Janeiro state, Brazil.

serreadas, e pelos capítulos em panículas corimbiformes vistosas. O exame do holótipo de $B$. lundii DC. confirma que este binômio trata-se de um sinônimo de $B$. serrulata (Müller 2006, Heiden 2009), diferente do posicionamento adotado por Barroso (1976), que aplicou equivocadamente o nome $B$. lundii para os espécimes de $B$. stylosa com lâminas lanceoladas.

15. Baccharis stylosa Gardner, London J. Bot., 4: 120. 1845. Ilustração: Malagarriga (1976).

Fig. 20

Arbustos ou subarbustos $0,1-5 \mathrm{~m}$ alt., eretos. Caule e ramos aparentemente glabros. Folhas com pecíolo 0,3-1,4 cm compr.; lâmina $1,7-8,3 \times 0,7-3,4 \mathrm{~cm}$, discolor, face abaxial fosca, face adaxial brilhosa, coriácea, oblonga, ovada, lanceolada ou elíptica, ápice agudo ou acuminado, base cuneada ou atenuada; 3 nervuras acródromas basais ou 10-12 mm suprabasais ou nervação actinódroma, ambas as faces resinosas, pubérulas ou aparentemente glabras. Panículas $1-16 \times 2-19 \mathrm{~cm}$, corimbiformes ou piramidais, terminais, congestas ou laxas; pedúnculos 1-5 $\mathrm{mm}$ compr. Capítulo masculino 2,8-4,5 mm alt.; invólucro 2,2-3,5 × 2,2-5,7 mm, 3-4-seriado; brácteas involucrais externas orbiculares ou ovadas, medianas ovadas, internas oblongas, ápice denteado, margens inteiras, escariosas.
Flores masculinas 12-16; corola 2,2-2,9 mm compr., tubo $0,9-1,3 \mathrm{~mm}$ compr., fauce $0,2-0,4$ mm compr., lacínias 0,9-1,2 mm compr.; anteras inclusas; estilete 2,5-4 mm compr.; papilho 2-2,7 $\mathrm{mm}$ compr., ápice levemente espessado. Capítulo feminino 2,2-4,8 mm alt.; invólucro 2,2-3,7 mm, 1,2-4,6 mm, 4-5-seriado; brácteas involucrais externas e medianas ovadas, internas oblongas, ápice e margens inteiros, escariosos. Flores femininas 34-55; corola 1,2-1,6 mm compr., ápice truncado, coroa subapical de tricomas presente; estilete 1,8-2,4 mm compr. Cipselas 0,7-1 $\mathrm{mm}$ compr., cilíndricas, levemente encurvadas, 4-6-costadas, pubérulas; papilho 1,6-2,8 mm compr., não acrescente.

Material selecionado: Itatiaia, G. Heiden 927, 928 (RB). Macaé, IX.1998, L.C. Giordano 2157 (RB). Nova Friburgo, 7.XI.1982, C. Farney 152 (RB). Petrópolis, 25.IX.1980, G. Martinelli 7398 (RB). Resende, 12.IX.2007, G. Heiden 830 (PEL, RB). Rio de Janeiro, 13.XI.1988, R.L. Esteves 324 (R). Santa Maria Madalena, 17.IX.1986, C. Farney 1185 (R, RB). Teresópolis, IX.1868, A.F.M. Glaziou 2848 (R).

Baccharis stylosa é restrita ao Sudeste do Brasil (ES, MG, RJ, SP), ocorrendo nos Biomas Cerrado e Mata Atlântica. No estado do Rio de Janeiro (Fig. 19) ocorre em altitudes que variam de 800 a $2700 \mathrm{~m}$, sendo comum tanto em refúgios ecológicos montanos (inselbergues) como altimontanos (campos de altitude). Trata-se de uma espécie heliófila associada a fendas em afloramentos rochosos ou solos rasos sobre a rocha. Fértil o ano inteiro, com pico de floração entre setembro e dezembro. A dispersão das cipselas ocorre logo após a floração. Alecrimdas-pedras (Heiden 860, 861).

Baccharis stylosa tem expressiva variação no tamanho das folhas e capitulescências. O estudo de espécimes em herbário e em campo permitiu observar que a expressão de caracteres morfológicos não está relacionada com a distribuição geográfica e nem é determinada pelo gradiente altitudinal. Barroso (1976) considerou espécimes com folhas menores (4-6 cm compr.), ovadas e com ápice agudo como B. stylosa, e espécimes com folhas maiores ( $8-9 \mathrm{~cm}$ compr.), lanceoladas e com ápice acuminado, como $B$. lundii, binômio cuja análise do tipo confirma tratar-se de um sinônimo de $B$. serrulata, conforme apontado previamente por Müller (2006) e Heiden (2009) 


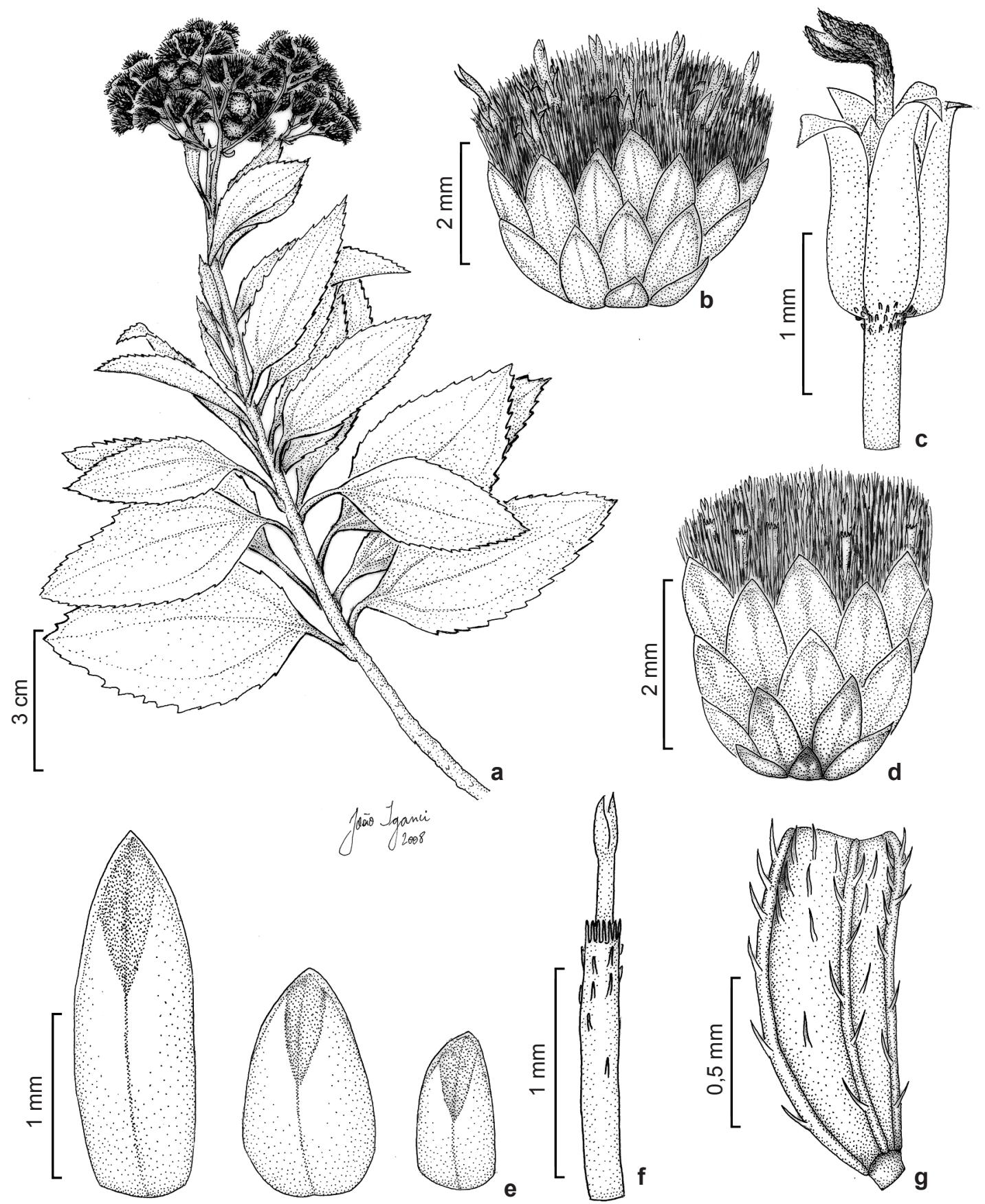

Figura 20 - Baccharis stylosa Gardner: a. ramo florífero, planta masculina; b. capítulo masculino; c. flor masculina (papilho removido); d. capítulo feminino; e. brácteas involucrais do capítulo feminino; f. corola e estilete da flor feminina; g. cipsela (a, d-g: Heiden 927; b, c: Heiden 928).

Figure 20 - Baccharis stylosa Gardner: a. flowering shoot, male plant; b. male capitulum; c. male floret (pappus removed); d. female capitulum; e. phyllaries of female capitulum; f. corolla and style of female floret; g. cypsela (a, d-g: Heiden 927; b, c: Heiden 928). 
IV. Baccharis subgen. Molina sect. Trinervatae DC., Prodr. 5: 399. 1836.

A seção Trinervatae corresponde ao grupo Baccharis trinervis sensu Müller (2006) e está representada por sete espécies com ocorrência nas Américas Central e do Sul. No Brasil, ocorrem quatro espécies, todas em bordas de florestas ou áreas secundárias em regeneração, das quais apenas $B$. quitensis Kunth não ocorre no território fluminense. Barroso (1976) reuniu os táxons desta seção no Grupo Anomala, em conjunto com $B$. anomala DC., espécie do subgen. Molina sect. Scandentes Cuatrec., que não ocorre no estado do Rio de Janeiro, e distinta da sect. Trinervatae por apresentar folhas com margens crenadas e capítulos femininos destituídos de páleas.

As espécies do Rio de Janeiro se distinguem pelo hábito arbustivo-lianescente, caule cilíndrico, estriado, folhas desenvolvidas, com ambas as faces nitidamente pilosas, glabrescentes, ou aparentemente glabras e margens inteiras; panículas ou racemos piramidais, corimbiformes ou glomeriformes; capítulos femininos com clinanto paleáceo; corola das flores femininas truncada e com uma coroa subapical de tricomas bisseriados; e cipselas glabras ou pubérulas, com papilho unisseriado, acrescente.

16. Baccharis bifrons Baker in Martius, $\mathrm{Fl}$. Bras. 6(3): 54. 1882. Ilustração: Malagarriga (1976).

Fig. 21

Arbustos ou subarbustos, 1-3 m alt., eretos ou escandentes, pubescentes. Folhas com pecíolo 2-5 mm compr.; lâmina $1,7-5,5 \times 0,5-2,1 \mathrm{~cm}$, cartácea, fosca, discolor, pubescente, elíptica, lanceolada ou ovada, ápice agudo, base cuneada ou arredondada; nervação actinódroma; folhas jovens com indumento viloso, constituído por tufos de tricomas filiformes e por tricomas glandulares bisseriados, denso e persistente na face abaxial, face adaxial glabrescente. Panículas glomeriformes ou corimbiformes, $0,7-2,8 \times 1,1-3,7 \mathrm{~cm}$; terminais; pedúnculos 1-3,6 mm compr. Capítulo masculino 4,5-4,9 mm alt.; invólucro 4,5-4,9 × 4,6-6,7 mm, 3 -seriado, campanulado; brácteas involucrais externas ovadas, medianas e internas lanceoladas ou linear-lanceoladas, face abaxial com tricomas filiformes, ápice fimbriado, margens estreitamente escariosa, fimbriada. Flores masculinas 20-35; corola 3,5-4 mm compr., tubo $0,9-1,6 \mathrm{~mm}$ compr.; fauce $0,1-0,5 \mathrm{~mm}$ compr., lacínias $1-2$ $\mathrm{mm}$ compr.; anteras levemente exsertas; estilete 3,5-4,4 mm compr.; papilho 3-3,7 mm compr., ápice levemente espessado. Capítulo feminino 4-7,6 mm alt.; invólucro 3,1-4,6 × 3,7-6,7 mm, 3-4-seriado, campanulado; brácteas involucrais externas elípticas, medianas, internas e páleas lanceoladas ou linear-lanceoladas, longamente atenuadas, e tricomas filiformes, ápice fimbriado, margens longamente fimbriadas, escariosas. Flores femininas 50-90; corola 1,4-2,1 mm compr.; estilete 3,1-4,2 mm compr. Cipselas 1-1,7 mm compr.; cilíndricas, levemente encurvadas; 5-7-costadas, tricomas filiformes simples; papilho 2,7-4,6 mm compr.

Material selecionado: Armação dos Búzios, $D$. Fernandes 28 (RB). Arraial do Cabo, 28.XI.2007, G. Heiden 917 (RB). Cabo Frio, 1.X.1966, D. Sucre 1163 (HB, RB). Iguaba Grande, C.A.L. Oliveira 1719 (GUA).

Baccharis bifrons é restrita ao estado do Rio de Janeiro (Fig. 22) no Bioma Mata Atlântica, sendo microendêmica do Centro de Diversidade Vegetal de Cabo Frio. Ocorre compondo formações arbustivas e em bordas de matas secas e matas de restinga. Floresce e frutifica entre agosto e janeiro.

Barroso (1976) considerou B. bifrons uma "espécie duvidosa". Müller (2006) reconheceu a validade de $B$. bifrons, porém assinalou a necessidade de estudo de material adicional para a delimitação de seus limites com $B$. cinerea. $\mathrm{O}$ estudo das coleções de herbários abrangendo toda a área de distribuição de $B$. bifrons e $B$. cinerea, em conjunto com observações em campo, permitiu delimitar morfologicamente ambas as espécies e definir suas áreas de ocorrência. Baccharis bifrons é caracterizada pelas folhas com 3 nervuras acródromas basais, indumento viloso, mais conspícuo nas folhas jovens, constituído por tufos de tricomas filiformes, flores masculinas com corola maior (3,5-4 mm compr.), corola feminina geralmente maior (1,4-2,1 mm compr.), estilete maior (3,1$4,2 \mathrm{~mm}$ compr.) e cipselas geralmente maiores (1-1,7 mm compr.), enquanto que $B$. cinerea possui folhas com 3 nervuras acródromas suprabasais ou 5 basais, indumento tomentoso constituído por tricomas arbusculares, formados pela fusão de tricomas flagelados e filiformes, 


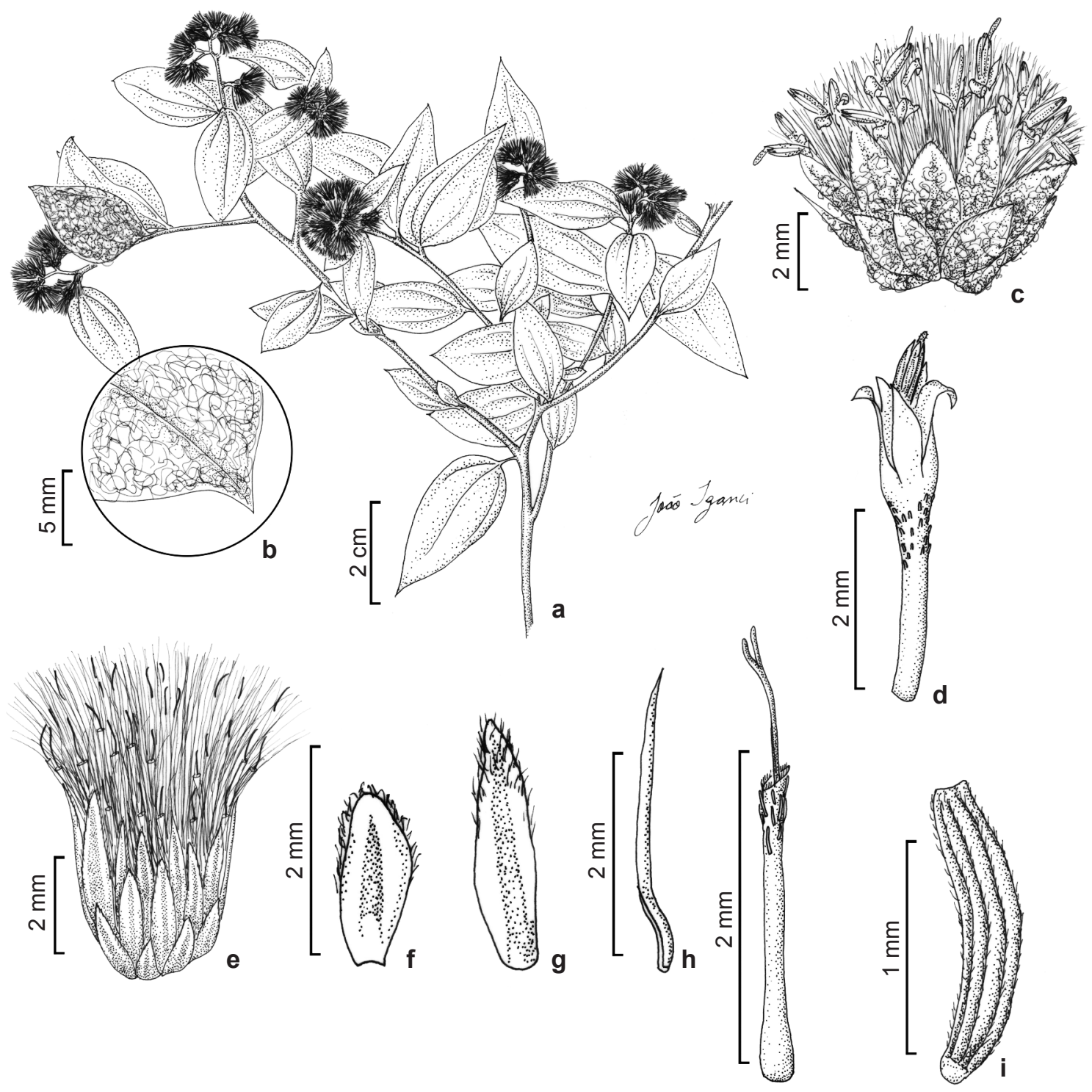

Figura 21 - Baccharis bifrons Baker: a. ramo florífero, planta feminina; b. face abaxial da folha; c. capítulo masculino; d. flor masculina (ovário vestigial e papilho removidos); e. capítulo feminino; F. brácteas involucrais do capítulo feminino; g. pálea; h. corola e estilete da flor feminina; i. cipsela (a, b, e-h: Farney 4802; c, d: Fernandes 28; I: Sucre 1163).

Figure 21 - Baccharis bifrons Baker: a. flowering shoot, female plant; b. leaf abaxial surface; c. male capitulum; d. male floret (pappus and vestigial ovary removed); e. female capitulum; f. phyllaries of female capitulum; g. palea; h. corolla and style of female floret; i. cypsela (a, b, e-h: Farney 4802; c, d: Fernandes 28; i: Sucre 1163).

e geralmente menores comprimentos da corola das flores masculinas $(2,2-3,4 \mathrm{~mm}$ compr.), da corola feminina $(1-1,75 \mathrm{~mm})$, do estilete (1,4-2,6 mm compr.) e das cipselas $(0,9-1,3$ $\mathrm{mm}$ compr.). Além disso, estas espécies são alopátricas, pois $B$. bifrons é endêmica da região de Cabo Frio e B. cinerea ocorre desde São Paulo até o Ceará.
17. Baccharis cinerea DC., Prodr. 5: 400. 1836. Baccharis trinervis var. cinerea (DC.) Baker in Martius, Fl. bras. 6(3): 73. 1882. Ilustração: Malagarriga (1976).

Fig. 23

Arbustos ou subarbustos, $0,75-5 \mathrm{~m}$ alt., eretos ou escandentes, pubescentes. Folhas com pecíolo $0,15-0,9 \mathrm{~cm}$ compr.; lâmina 1,7-8,6 × 0,5-3,8 cm, cartácea, fosca, cinérea, discolor, 
elíptica, lanceolada ou ovada, ápice agudo, base cuneada ou arredondada; 5 nervuras acródromas basais, ou nervação actinódroma 1,3-8,5 mm suprabasal; folhas jovens tomentosas, face adaxial glabrescente, tricomas arbusculares formados pela fusão de tricomas flagelados e filiformes. Panículas glomeriformes ou corimbiformes, $1-4,8 \times 1,6-7,3$ $\mathrm{cm}$, terminais e/ou axilares; pedúnculos $0,1-6,5$ $\mathrm{mm}$ compr. Capítulo masculino 3,5-6,1 mm alt.; invólucro 2-3,4 × 3,3-6 mm, 3-4-seriado; brácteas involucrais externas e medianas ovadas, internas elípticas, face abaxial com tricomas filiformes, ápice inteiro ou curtamente fimbriado, margens inteiras, escariosas. Flores masculinas 12-34; corola 2,2-3,4 $\mathrm{mm}$ compr., glabra, tubo $1-1,3 \mathrm{~mm}$ compr., fauce 0,6-1,2 mm compr., lacínias $0,6-1,2 \mathrm{~mm}$ compr.; anteras exsertas; estilete 3,3-4,6 mm compr.; papilho 2,1-3,5 mm compr., ápice levemente espessado. Capítulo feminino $4-6,9 \mathrm{~mm}$ alt.; invólucro 2,4-3,5 × 3-5,5 cm, 3-4-seriado, campanulado; brácteas involucrais verde ou marrons, externas ovadas, medianas elípticas, internas e páleas linearelípticas, face abaxial com tricomas filiformes, ápice curtamente fimbriado, margens escariosas e denteadas; flores 50-120; corola 1-1,75 mm compr., ápice truncado, coroa subapical de tricomas esparsos presente; estilete 1,4-2,6 mm compr. Cipselas 0,9$1,3 \mathrm{~mm}$ compr., levemente curvada; 4-6-costadas, glabrescentes, tricomas curtos e esparsos; papilho 1,6-3,8 mm compr.

Material selecionado: Bom Jesus de Itabapoana, 16.X.1982, C. Rizzini 241871 (GUA). Santo Antônio de Pádua, 21.IX.2005, C.A.L. Oliveira 2767 (GUA). Trajano

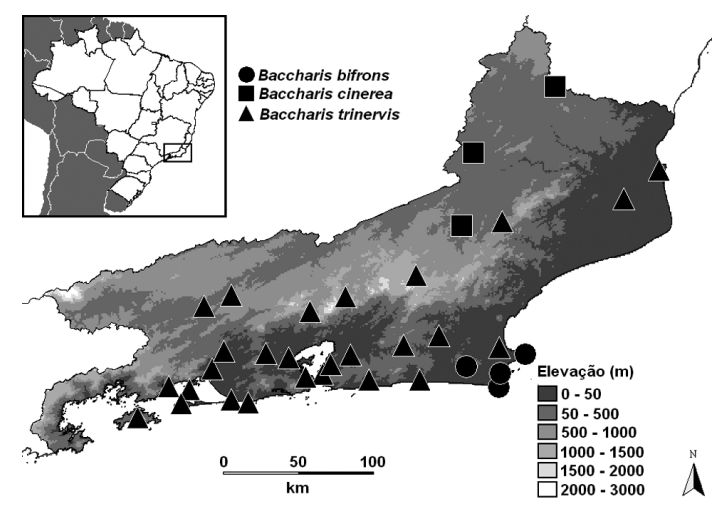

Figura 22 - Distribuição geográfica de Baccharis bifrons $\operatorname{Baker}(\bullet)$, B. cinerea DC. (ロ) e B. trinervis Pers. (A) no estado do Rio de Janeiro.

Figure 22 - Geographic distribution of Baccharis bifrons

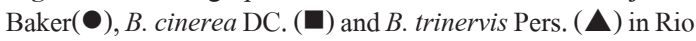
de Janeiro state, Brasil. de Moraes, 26.VII.1996, C.E.B. Pereira 306 (GUA). Material adicional selecionado: ALAGOAS: Colônia Leopoldina, 2.XI.1957, A. Lima 2774 (RB). BAHIA: Jequié, 12.X.1983, A.M.V. Carvalho 1933 (CEPEC). S.1., s.d., J.S. Blanchet 1564 (síntipo G-DC-4x, foto; MG). S.1., 1831, J.S. Blanchet 77 (síntipo G-DC, foto). S.1., s.d., P. Salzmann 4830 (síntipo G-DC, foto!). CEARÁ: São Benedito, 5.I.1942, P. Bezerra (RB 362577). ESPÍRITO SANTO: Pinheiros, 19.I.2008, G. Heiden 952 (RB). MINAS GERAIS: Carangola, 15.IX.1989, L.S. Leoni 864 (RB). PARAÍBA: Areia, 15.X.1944, J.M. Vasconcellos 62 (RB). PERNAMBUCO: Brejo da Madre de Deus, 18.I.1999, L.M. Nascimento 263 (RB). RIO GRANDE DO NORTE: Martins, 2.III.2006, R.T. Queiroz 612 (UFRN).

Baccharis cinerea é restrita ao Brasil, sendo encontrada nas Regiões Nordeste (AL, BA, CE, PB, PE, RN) e Sudeste (ES, MG, RJ, SP), ocorrendo nos Biomas Caatinga e Mata Atlântica, em bordas de matas estacionais, matas de tabuleiro e brejos de altitude, tanto em áreas primárias, como secundárias em regeneração. No estado do Rio de Janeiro (Fig. 22) ocorre em matas estacionais e matas de tabuleiro no norte do estado, em altitudes entre 50-500 m, vegetando em bordas. Floresce e frutifica de agosto a abril.

Baker (1882) considerou B. cinerea como uma variedade de $B$. trinervis, enquanto Barroso (1976) sinonimizou-a a $B$. trinervis var. rhexioides. Müller (2006) reconheceu B. cinerea como um táxon distinto, entretanto, salientou a necessidade de uma investigação de seus limites com B. bifrons. $\mathrm{O}$ estudo de coleções de toda a área de ocorrência da espécie permitiu reconhecer $B$. cinerea e diferenciá-la de $B$. bifrons, conforme discutido previamente. Primeira citação para os estados do Espírito Santo, Minas Gerais, Rio de Janeiro e São Paulo, anteriormente referida vagamente para o leste do Brasil (Região Nordeste).

18. Baccharis trinervis Pers., Syn. pl. 2: 423.1807. Conyza trinervis Lam., Encycl. 2: 85. 1786, non Conyza trinervia Miller, 1768. Heterothalamus trinervis (Lam.) Hook. \& Arn., J. Bot. (Hooker) 3: 43. 1840. Pseudobaccharis trinervis (Lam.) V.M.Badillo, Bol. Soc. Venez. Ci. Nat. 10: 306. 1946. Psila trinervis (Lam.) Cabrera, Bol. Soc. Argent. Bot. 5: 211. 1955. Ilustrações: Cuatrecasas (1967, 1969); Malagarriga (1976); Cabrera (1978); Müller (2006).

Fig. 24

Trepadeiras, às vezes arbustos ou subarbustos, $1-5 \mathrm{~m}$ alt., eretos. Folhas com pecíolo $0,2-0,8 \mathrm{~cm}$ compr.; lâmina 0,9-11,5 × 0,7-3,4 cm, resinosa, brilhosa, levemente discolor ou concolor, cartácea, 


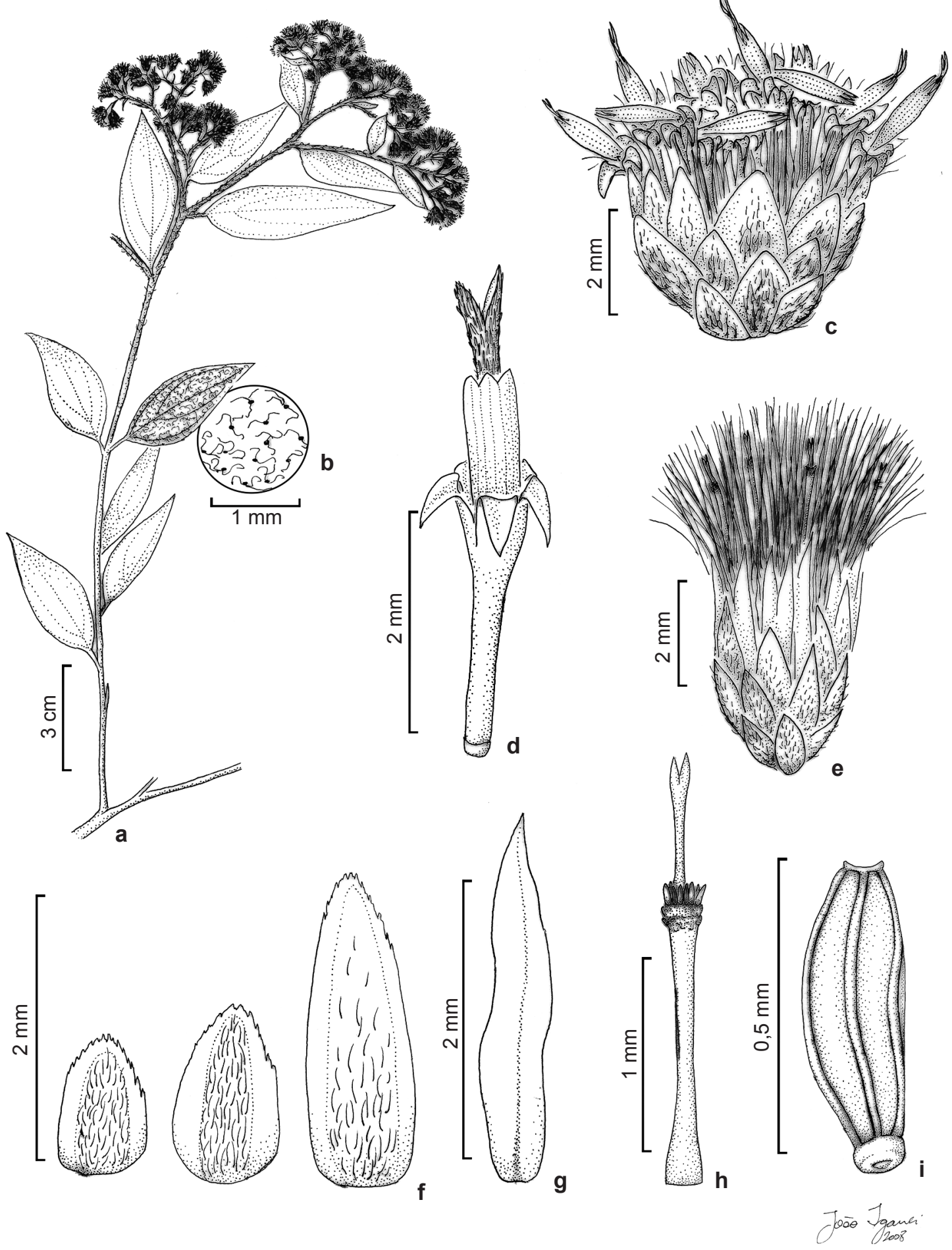

Figura 23 - Baccharis cinerea DC.: a. ramo florífero, planta masculina; b. face abaxial da folha; c. capítulo masculino; d. flor masculina (papilho removido); e. capítulo feminino; f. brácteas involucrais do capítulo feminino; g. pálea; $h$. corola e estilete da flor feminina; i. cipsela (a-d, i: Carvalho 1933; e-h: Heiden 952).

Figure 23 - Baccharis cinerea DC.: a. flowering shoot, male plant; b. abaxial leaf surface; c. male capitulum; d. male floret (pappus removed); e. female capitulum; f. phyllaries of female capitulum; g. palea; h. corolla and style of female floret; i. cypsela (a-d, i: Carvalho 1933; e-h: Heiden 952). 


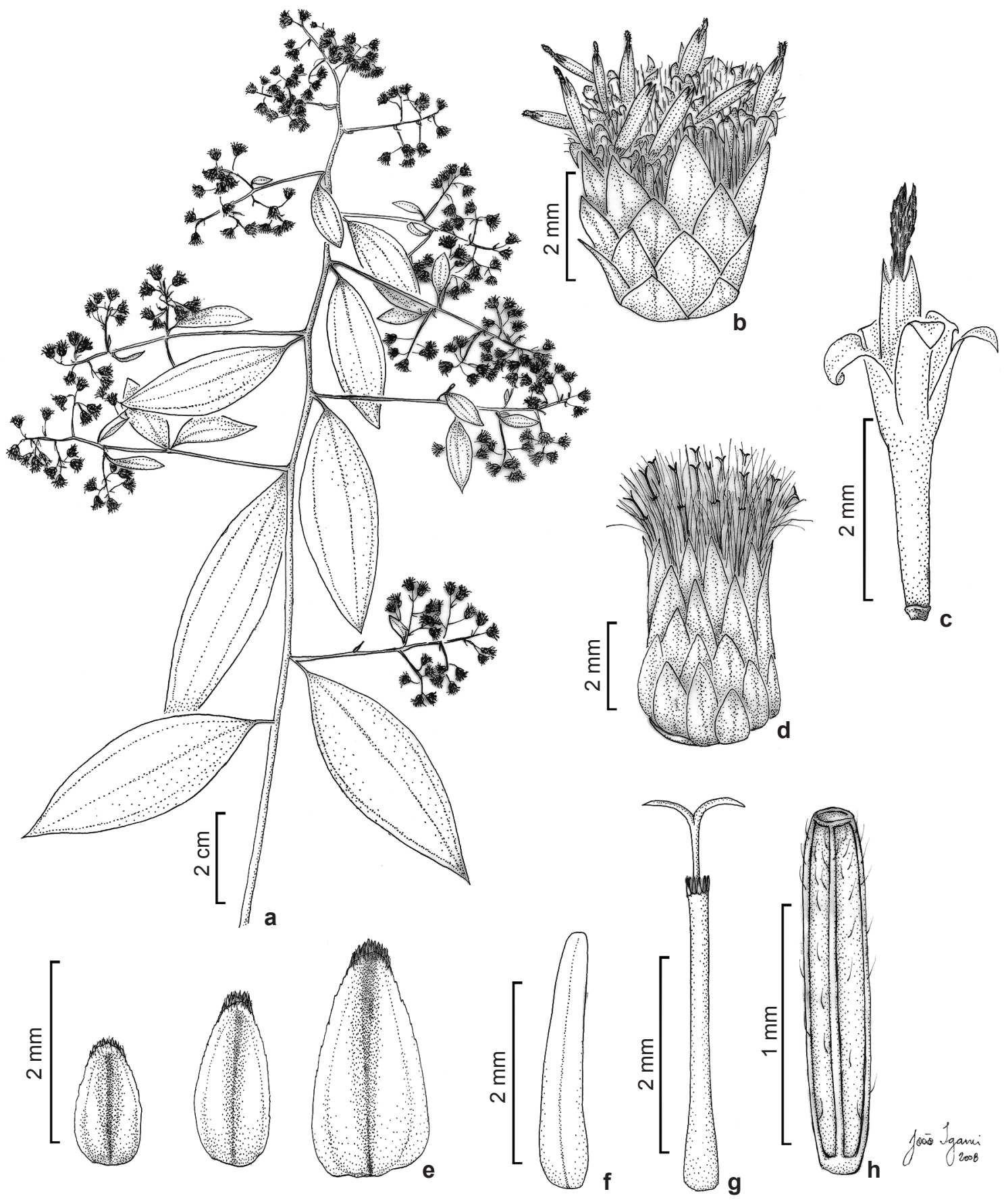

Figura 24 - Baccharis trinervis Pers.: a. ramo florífero, planta masculina; b. capítulo masculino; c. flor masculina (papilho removido); d. capítulo feminino; e. brácteas involucrais do capítulo feminino; f. pálea; g. corola e estilete da flor feminina; h. cipsela (a: Silva 40; b, c: Góes 670; d-g: Heiden 770; h: Duarte 4854). Figure 24 - Baccharis trinervis Pers.: a. flowering shoot, male plant; b. male capitulum; c. male floret (pappus removed); d. female capitulum; e. phyllaries of the female capitulum; f. palea; g. corolla and style of female floret; h. cypsela (a: Silva 40; b, c: Góes 670; d-g: Heiden 770; h: Duarte 4854). 
lanceolada, oblanceolada, obovada ou ovada, ápice agudo, base cuneada ou arredondada; nervação actinódroma; glabrescente, tricomas filiformes esparsos. Panículas ou racemos 3,5-27 × 2-21 cm, terminais e/ou axilares, piramidais; pedúnculos $0,1-0,3 \mathrm{~cm}$ compr. Capítulo masculino $3,2-6 \mathrm{~mm}$ alt.; invólucro 2-3,6 × 2,9-4,5 mm, 3-4-seriado, campanulado; brácteas involucrais externas ovadas, medianas elípticas, internas lanceoladas ou linear-lanceoladas, face abaxial com tricomas filiformes esparsos, ápice inteiro a denteado, margens escariosas. Flores masculinas 20-40; corola 2,5-4,5 mm compr., tubo $1-2,2 \mathrm{~mm}$ compr., fauce $0,3-1 \mathrm{~mm}$ compr., lacínias $1-1,5 \mathrm{~mm}$ compr.; anteras exsertas; estilete 2-4,5 mm compr.; papilho 2-4 mm compr., ápice levemente espessado. Capítulo feminino 3,3-9 mm alt.; invólucro 2,1-4,4 $\times$ 2,6-4,8 mm, 5-7-seriado, cilíndrico; brácteas involucrais externas ovadas, medianas elípticas, internas e páleas lanceoladas ou linear-lanceoladas, ápice denteado, margens inteiras, escariosas. Flores femininas 45-135; corola 2,5-4 mm compr., ápice truncado, coroa subapical de tricomas presente; estilete $2-6,5 \mathrm{~mm}$ compr. Cipselas $0,8-1,5 \mathrm{~mm}$ compr., cilíndricas, 5-7-costadas, pubérulas; papilho $2-5 \mathrm{~mm}$ compr.

Material selecionado: RIO DE JANEIRO: Angra dos Reis, Ilha Grande, 15.XII.2000, F. Pinheiro 622 (HB). Armação dos Búzios, 27.VIII.2004, H.G.D. Rasa 418 (HB, RB). Barra do Piraí, 19.V.1986, J.P.P. Carauta et al. 5325 (CEPEC, GUA). Campos dos Goytacazes, VIII.1939, A.J. Sampaio 8440 (R). Duque de Caxias, 6.VI.1938, A. Passarelli 91 (R). Engenheiro Paulo de Frontin, 9.VII.1998, M.C.F. Santos et al. 207 (RFFP). Ilha Furtada, Baía de Sepetiba, 25.XII.1967, D. Sucre 2060 (HB, RB). Itaguaí, VII.1952, H. Monteiro Filho 3618 (RBR). Mangaratiba, Ilha da Marambaia, 14.IX.2007, T.A. Amorim (RBR 29515). Maricá, 5.VII.1996, R.L. Esteves 915, 916 (R). Niterói, 26.VI.2003, C.A.L. Oliveira 2186 (GUA). Nova Friburgo, 17.XII.1953, $P$. Capel (FCAB 817). Nova Iguaçu, 12.VII.1995, I.M. Silva 386 (RBR). Petrópolis, VI.1944, O.C. Góes 670 (RB). Rio de Janeiro, 23.VI.1959, A.P. Duarte 4854 (HB, RB). Rio Bonito, 13.VI.1974, P.P.H. Laclette 146 (R). Santa Maria Madalena, 17.V.2007, G. Heiden et al. 770 (RB). São Gonçalo, 31.VII.1994, D.C.P. Silva et al. 121 (GUA) São João da Barra, 21.VII.2003, M.C. Gaglianone 137 (RB). Saquarema, D.S.D. Araújo 9623 (GUA). Seropédica, 14.VIII.1949, H. Monteiro Filho 2650 (RBR). Teresópolis, 8.IV.1959, A.P. Duarte 4715 (HB, RB). Vassouras, 25.VI.1944, F. Segadas-Vianna 506 (R). Material adicional selecionado: ACRE: Iquiri, 28.VIII.1951, W. Brockemann 130 (SP). Rio Branco, 3.X.1980, S.R. Lowrie et al. 367 (MG, R, RB). PERNAMBUCO: Brejo da Madre de Deus, 26.I.2000, A.M.
Silva et al. 40 (JPB). RONDÔNIA: Porto Velho to Cuiabá highway, 15.VIII.1968, E. Forero 7072 (MG, R, RB).

Baccharis trinervis apresenta ampla distribuição nas Américas Central e do Sul, ocorrendo no México, Guatemala, Honduras, Costa Rica, Panamá, Colômbia, Venezuela, Equador, Peru, Bolívia, Paraguai, Brasil e Argentina. No Brasil, é encontrada nas Regiões Norte (AC, RO), Nordeste (BA, CE, PE), Centro-Oeste (DF, GO, MS, MT), Sudeste (ES, MG, RJ, SP) e Sul (PR, $\mathrm{SC}, \mathrm{RS})$, nos Biomas Amazônia, Cerrado e Mata Atlântica. No estado do Rio de Janeiro (Fig. 22) ocorre desde o nível do mar, em restingas, até altitudes próximas a $900 \mathrm{~m}$, em formações de Floresta Ombrófila Densa. Apresenta preferência por bordas de mata, clareiras e áreas secundárias em regeneração. Floresce e frutifica ao longo de todo o ano. Cambará-rebentão (Smith 71), erva-desantana (Macedo 159).

Baccharis trinervis assemelha-se com $B$. bifrons e $B$. cinerea, mas pode ser diferenciada pelas folhas resinosas e aparentemente glabras e pelas panículas ou racemos piramidais.

Conservação de Baccharis subgen. Molina no estado do Rio de Janeiro

Com base nos dados levantados durante os estudos taxonômicos em Baccharis, as espécies ocorrentes no território fluminense foram avaliadas quanto ao estado de conservação conforme os critérios da IUCN (2001). Os resultados obtidos estão sumarizados na Tabela 1 e são discutidos a seguir. Duas espécies foram consideradas em perigo (EN), duas espécies vulneráveis (VU), três quase ameaçadas (NT) e dez fora de perigo (LC). Além destas, uma espécie não possui dados suficientes (DD) para definir o estado de conservação.

\section{Em Perigo (EN)}

Duas espécies foram enquadradas no critério "Em Perigo" no estado do Rio de Janeiro. Baccharis burchellii possui poucas amostras em herbários e durante as expedições de campo apenas três espécimes foram observados no Parque Nacional do Itatiaia. Além de ocorrer com freqüência reduzida, uma extensa área do habitat de campos de altitude vem sofrendo com incêndios e outras perturbações antrópicas. Devido à baixa freqüência e perda de qualidade do habitat da espécie no estado do Rio de Janeiro, B. burchellii é considerada Em Perigo: EN A1ac,2,4 B1ab(i, ii, iii, v). Além do território fluminense, a espécie ocorre também em Minas 
Tabela 1 - Síntese do estado de conservação das espécies de Baccharis subgen. Molina (Asteraceae; Astereae) no estado do Rio de Janeiro, conforme os critérios da IUCN (2001).

\begin{tabular}{lc}
\hline Espécie & Estado de conservação \\
\hline Baccharis altimontana Heiden, Baumgratz \& Esteves & $\mathrm{NT}$ \\
Baccharis bifrons Baker & $\mathrm{VU}$ A3c,B1b (iii) \\
Baccharis breviseta DC. & LC \\
Baccharis burchellii Baker & EN A1ac,2,4 B1ab (i, ii, iii, v) \\
Baccharis cinerea DC. & EN Ba (iii) \\
Baccharis crispa Spreng. & LC \\
Baccharis glaziovii Baker & NT \\
Baccharis glutinosa Pers. & LC \\
Baccharis junciformis DC. & LC \\
Baccharis myriocephala DC. & LC \\
Baccharis organensis Baker & VU B1a,2ab (iii) \\
Baccharis oxyodonta DC. & LC \\
Baccharis punctulata DC. & LC \\
Baccharis regnellii Sch.Bip. ex Baker & DD \\
Baccharis serrulata (Lam.) Pers. & LC \\
Baccharis stylosa Gardner & NT \\
Baccharis trinervis Pers. & LC \\
Baccharis vulneraria Baker & LC \\
\hline
\end{tabular}

Gerais e São Paulo. Baccharis cinerea ocorre nas florestas estacionais e matas de tabuleiro do norte do estado do Rio de Janeiro. Nesta região existem poucos remanescentes florestais, sendo que nenhum dos locais onde a espécie foi coletada pertence a uma unidade de conservação. Devido à carência de áreas de proteção nos habitats da espécie e à elevada fragmentação dos remanescentes florestais do norte fluminense, B. cinerea é considerada "Em Perigo": EN Ba(iii). Além do estado do Rio de Janeiro, a espécie ocorre também no Espírito Santo, Minas Gerais, São Paulo e Região Nordeste do Brasil, onde é encontrada em áreas protegidas.

\section{Vulneráveis (VU)}

Duas espécies foram definidas como "Vulneráveis" no estado do Rio de Janeiro. Baccharis bifrons possui distribuição geográfica restrita ao Centro de Diversidade Vegetal de Cabo Frio. Nesta área limitada, os habitats ocupados pela espécie vêm sendo reduzidos ou degradados, devido principalmente a expansão urbana e a especulação imobiliária, visto que se trata de uma região sobre-explorada pelo turismo. Devido a estes fatores a espécie é considerada "Vulnerável": VU $\mathrm{A} 3 \mathrm{c}, \mathrm{B} 1 \mathrm{~b}$ (iii). Baccharis organensis é encontrada na vertente sul dos campos de altitude do estado do Rio de Janeiro, vegetando nas escarpas, bordas de matas nebulares e afloramentos rochosos. As populações da espécie encontram-se isoladas nos cumes das cadeias da Serra do Itatiaia, Serra dos Órgãos, Pico da Caledônia e Pico do Desengano, e estão sujeitas a extinções pontuais causadas por eventos estocásticos. Devido a pequena área total de ocupação da espécie, reduzido número de populações e pressões antrópicas que afetam a vegetação de altitude, $B$. organensis é considerada vulnerável no território fluminense: $\mathrm{VU}$ B1a,2ab(iii). Além do estado do Rio de Janeiro, a espécie é encontrada também em Minas Gerais, São Paulo e nos estados da Região Sul. 
Quase Ameaçadas (NT)

Três espécies foram incluídas na categoria Quase Ameaçadas (NT) no estado do Rio de Janeiro. Baccharis glaziovii é característica em bordas de florestas altimontanas, enquanto que $B$ altimontana e $B$. stylosa são encontradas principalmente em afloramentos rochosos nos campos de altitude. Embora essas espécies formem populações densas, estas se restringem a poucas localidades ou ocorrem em áreas limitadas, sendo que eventos estocásticos poderiam causar a extinção de populações isoladas sem possibilidade de regeneração. Isso porque, mesmo estando em áreas oficialmente protegidas, muitos dos ambientes onde estas espécies ocorrem sofrem impactos adversos provenientes de atividades humanas. Considerando que estes fatores afetam negativamente a conservação dos habitats, estas espécies são avaliadas como quase ameaçadas.

\section{Fora de Perigo (LC)}

No estado do Rio de Janeiro, 10 espécies foram consideradas Fora de Perigo (LC) ou não-ameaçadas. A maior parte delas possui dispersão ampla no território estadual e mesmo no Brasil. Algumas são características de locais degradados ou áreas secundárias em regeneração ou toleram diferentes graus de pressão antrópica, outras são comuns em margens de formações florestais ou mesmo em clareiras na mata. Estas espécies não foram enquadradas em nenhuma categoria de ameaça devido à dispersão ampla, baixa especificidade de habitat ou ocorrência comum em áreas perturbadas. Baccharis crispa medra em margens de caminhos nos campos de altitude, tanto em áreas primárias quanto secundárias. Baccharis breviseta, B. glutinosa e B. myriocephala ocorrem em áreas primárias, onde fatores edáficos limitam o desenvolvimento de vegetação florestal, ou em vegetação secundária, como pioneiras em áreas em regeneração. Baccharis oxyodonta, B. punctulata, $B$. serrulata, $B$. trinervis e $B$. vulneraria ocorrem nas transições naturais entre campo e vegetação arbustiva ou herbácea e também são comuns em bordas de florestas, em locais que sofreram distúrbios como a abertura de trilhas ou clareiras na mata. Baccharis junciformis é comum em brejos e margens de lagoas nas restingas ou em brejos e locais com solos hidromórficos localizados até cerca de $800 \mathrm{~m}$ de altitude.

\section{Dados Deficientes (DD)}

Uma espécie não conta com dados suficientes para definir o estado de conservação e foi considerada na categoria "Dados Deficientes" (DD). Baccharis regnellii possui dois registros de coleta para o município de Nova Friburgo, entretanto a espécie não foi localizada durante trabalho de campo recente. Desta forma, as informações disponíveis sobre a espécie no estado foram consideradas insuficientes. Novas coletas e observações de campo são necessárias para assegurar o estado de conservação dessa espécie no território fluminense.

Espécies de Baccharis subgen. Molina excluídas da flora fluminense

Baccharis anomala DC. Pertencente à seção Scandentes Cuatrec., ocorre na Argentina, Uruguai e Brasil, nos estados de MG, SP, PR, SC e RS. Citada equivocamente por Jacques (1996) para o munícipio de Santa Maria Madalena, RJ, mas o espécime analisado (Rau 2249) foi coletado no município de Santa Maria, RS.

Baccharis aphylla (Vell.) DC. Pertencente à seção Aphyllae (Baker) O.Hoffm., ocorre na Bolívia e Brasil, nos estados de BA, MG, SP e PR. Exceto pela citação de Vellozo (1831) na Flora fluminensis, que abrangeu uma área territorial maior que os limites atuais do estado, não existem outras citações, assim como qualquer material coletado.

Baccharis articulata (Lam.) Pers. Pertencente à seção Caulopterae, ocorre na Bolívia, Paraguai, Argentina, Uruguai e Brasil, nos estados de MG, SP, PR, SC e RS. Referida por Barroso (1957) para a flora do Itatiaia, porém o espécime citado (Campos Porto 552, RB) não foi encontrado, assim como a espécie não foi observada em campo.

Baccharis milleflora (Less.) DC. Pertencente à seção Caulopterae, ocorre no Paraguai e Brasil, nos estados de MG, SP, PR, SC e RS. Citada por Jacques (1996) para o RJ, porém, durante a revisão de herbários foram encontrados apenas espécimes de B. myriocephala, equivocadamente identificados como B. milleflora.

Baccharis opuntioides Mart. ex Baker. Pertencente à seção Caulopterae e endêmica do Parque Nacional do Caparaó, na divisa entre ES e MG. Barroso (1976) e Schneider \& Boldrini (2008) citam para o RJ, porém os espécimes estudados pertencem a $B$. altimontana e B. crispa.

\section{Agradecimentos}

Os autores agradecem ao CNPq-PROTAX a bolsa de mestrado do primeiro autor durante o período de realização da dissertação de mestrado, ao Instituto Chico Mendes as autorizações de coleta, aos herbários 
consultados o apoio, aos dois revisores anônimos a revisão do manuscrito, ao João Iganci as ilustrações e à André Scarambone Zaú, Cecília Cronenberger de Faria, David e Isabel Miller, Denise Pinheiro da Costa, Elsie Franklin Guimarães, Izar Aximoff, Marcus Nadruz, Marina Wolowski Torres, Ronaldo Marquete, Sebastião José da Silva Neto, Vidal de Freitas Mansano e Viviane Stern da Fonseca-Kruel, o apoio à realização dos trabalhos de campo.

\section{Referências}

Ariza Espinar, L. 1973. Las espécies de Baccharis (Compositae) de Argentina Central. Boletim de la Academia Nacional de Ciencias de Cordoba 50: 1-305.

Baker, J.G. 1882. III. Asteroideae, Inuloideae. Compositae. In: Martius, C.F.P. \& Eichler, A.W. Flora brasiliensis. Fleischer, Monachii, Lipsiae, 6: 1-134.

Barroso, G.M. 1957. Flora do Itatiaia - Compositae. Rodriguésia 32: 175-241.

Barroso, G.M. 1976. Compositae - Subtribo Baccharidinae Hoffmann. Estudo das espécies ocorrentes no Brasil. Rodriguésia 28: 3-273.

Borges, R.A.X \& Forzza, R.C. 2008. A tribo Astereae (Asteraceae) no Parque Estadual do Ibitipoca, Minas Gerais, Brasil. Boletim de Botânica da Universidade de São Paulo 26: 131-154.

Cabrera, A.L. 1963. Flora de la Provincia de Buenos Aires. VI: Compuestas. Instituto Nacional de Tecnología Agropecuaria, Buenos Aires. 433p.

Cabrera, A.L. 1974. Compositae, compuestas. In: Burkart, A. (ed.). Flora ilustrada de Entre Ríos (Argentina). Buenos Aires, Instituto Nacional de Tecnología Agropecuaria 6: 106-538.

Cabrera, A.L. 1978. Flora de la Provincia de Jujuy. Coleccion Cientifica 13, pt. 10: Compositae. Buenos Aires, Instituto Nacional de Tecnología Agropecuaria. 725p.

Candolle, A.P. 1836. Prodromus systematis naturalis regni vegetabilis 5 - Sistens Calycereas et Compositarum tribus priores. Treuttel \& Würtz, Paris. 706p.

Corrêa, M.P. 1984. Dicionário das plantas úteis do Brasil e das exóticas cultivadas VI: CAR-E. Imprensa Nacional. Rio de Janeiro. 173p.

Cuatrecasas, J. 1967. Revisión de las especies colombianas del género Baccharis. Revista de la Academía Colombiana de Ciéncias Exactas, Físicas y Naturales 13: 5-102.

Cuatrecasas, J. 1969. Notas adicionales, taxonômicas y corológicas sobre Baccharis. Revista de la Academía Colombiana de Ciéncias Exactas, Físicas y Naturales 13: 201-226.

Diesel, S. 1987. Contribuição ao estudo taxonômico do gênero Baccharis Linnaeus (grupo Trimera) no
Rio Grande do Sul - Brasil. Pesquisas, Botânica 38: 91-126.

Fielding, R.R. 2001. Baccharis: a genus of the Asteraceae new to Canada. Proceedings of the Nova Scotian Institute of Science 41: 214-215.

Giuliano, D.A. 2001. Classificación infragenérica de las espécies Argentinas de Baccharis (Asteraceae, Astereae). Darwiniana 39: 131-154.

Heiden, G.; Iganci, J.R.V.; Bobrowski, V.L. \& Macias, L. 2007. Biogeografia de Baccharis sect. Caulopterae (Asteraceae) no Rio Grande do Sul, Brasil. Rodriguésia 58: 787-796.

Heiden, G. 2009. Estudos taxonômicos e conservação em Baccharis L. (Asteraceae, Astereae) no estado do Rio de Janeiro, Brasil. Dissertação de Mestrado. Instituto de Pesquisas Jardim Botânico do Rio de Janeiro, Rio de Janeiro. 254p.

Heiden, G.; Baumgratz, J.F.A. \& Esteves, R.L. 2009a. New species of Baccharis L. (Asteraceae, Astereae) from Rio de Janeiro state, Southeastern Brazil. Journal of the Botanical Institute of Texas 3: 139-145.

Heiden, G.; Iganci, J.R.V. \& Macias, L. 2009b. Baccharis sect. Caulopterae (Asteraceae, Astereae) no Rio Grande do Sul, Brasil. Rodriguésia 60: 943-983.

Heiden, G. \& Schneider, A.A. 2012. Baccharis. In: Lista de Espécies da Flora do Brasil. Jardim Botânico do Rio de Janeiro. Disponível em $<$ http:// floradobrasil.jbrj.gov.br/2010/FB005151>. Acesso em 29 Ago 2012.

Hellwig, F. 1993. The genera Pingraea Cassini and Neomolina Hellwig (Compositae-Astereae). Candollea 48: 203-219.

IBGE. 2004. Mapa de Biomas do Brasil. Primeira aproximação. Disponível em < http://www2.ibge. gov.br/download/mapas_murais/biomas_pdf.zip $>$. Acesso em 10 Jan 2009.

IUCN. 2001. IUCN Red List Categories and Criteria Version 3.1. Prepared by the IUCN Species Survival Commission. IUCN, Gland and Cambridge.

Jacques, E.L. 1996. Compositae. In.: Marques, M.C.M. (ed.). Espécies coletadas no estado do Rio de Janeiro e depositadas no Herbário RB. Instituto de Pesquisas Jardim Botânico do Rio de Janeiro, Rio de Janeiro. 107p.

Malagarriga Heras, R.P. [1976] 1977. Nomenclator baccharidinarum omnium. Memoria de la Sociedad de Ciencias Naturales La Salle 37: 129-224.

Müller, J. 2006. Systematics of Baccharis (Compositae-Astereae) in Bolivia, including an overview of the genus. Systematic Botany Monographs 76: 1-341.

Müller, J. 2010. World checklist of Baccharis L. (Compositae-Astereae). Disponível em $<$ http:// 
www2.uni-jena.de/biologie/spezbot/herbar/ Baccharis.htm>. Acesso em 10 Mar 2010.

Nesom, G.L. 1988. Baccharis sect. Baccharidastrum (Compositae: Astereae), including two monoecious and one dioecious species. Phytologia 65: 169-173.

Radford, A.E.; Dickison, W.C.; Massey, J.R. \& Bell, C. R. 1974. Vascular plant systematics. Harper \& Row, New York. 891p.

Schneider, A.A. \& Boldrini, I.I. 2008. Ocorrência de Baccharis opuntioides Mart. ex Baker (Asteraceae: Astereae) para a Região Sul do Brasil. Revista Brasileira de Biociências 6: 137-139.
Soria, N. 1993. Las espécies aladas de Baccharis utilizadas como medicinales em Paraguay. Rojasiana 1: 3-12.

Teodoro Luis, 'Irmão’ [Malagarriga Heras, R.P.]. 1949. De "Re-Botânica" 1. Boletim Informativo do Instituto Geobiológico La Salle 1: 11-14.

Teodoro Luis, 'Irmão' [Malagarriga Heras, R.P.]. 1954. Exsiccatae Baccharidinarum. I. Plantae Wilson-Hoehneana. Contribuições do Instituto Geobiológico Canoas 3: 1-20.

Vellozo, J.M.C. 1831 (1827). Florae fluminensis icone. Vol. 8. Senefelder, Paris. 1640p. 